


\title{
The value of immigrants' human capital for labour market integration
}

\author{
Andrey Tibajev
}

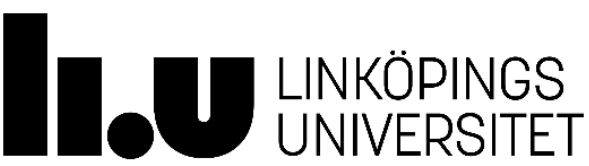

Linköping Studies in Arts and Sciences No. 824

Faculty of Arts and Sciences

Linköping 2022 
At the Faculty of Arts and Sciences at Linköping University, research and doctoral studies are carried out within broad problem areas. Research is organized in interdisciplinary research environments and doctoral studies mainly in graduate schools. Jointly, they publish the series Linköping Studies in Arts and Sciences. This thesis comes from Division of Migration, Ethnicity and Society (REMESO) at the Department of Culture and Society.

Distributed by:

Department of Culture and Society

Linköping University

58183 Linköping

Andrey Tibajev

The value of immigrants' human capital for labour market integration

\section{Edition 1:1}

ISBN 978-91-7929-117-4 (print)

ISBN 978-91-7929-118-1 (PDF)

https://doi.org/10.3384/9789179291181

(C) Andrey Tibajev

Department of Culture and Society, 2022

Cover image by Mattias Valenca

Printed by LiU-tryck

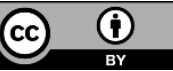

This work is licensed under the Creative Commons Attribution 4.o International License. To view a copy of this license, visit http://creativecommons.org/licenses/by/4.0/. 


\section{Abstract}

This dissertation focuses on the productive knowledge and skills, i.e., human capital, that immigrants bring from before immigration, as well as new human capital acquired in the destination country. The four studies included use registry and survey data to consider different aspects of labour market integration in Sweden, analysing how immigrants' human capital is used and valued in the Swedish labour market, and how this affects labour market outcomes.

Study I, co-authored with Carina Hellgren, analyses the effects of formal recognition of foreign higher education on employment and earnings.

Study II focuses on the value that domestic employers assign to immigrants' labour market experience from both before and after immigration.

Study III examines the link between experience of self-employment before immigration and the propensity to enter self-employment in the destination country.

Study IV explores immigrants' occupational mobility, testing whether there is a trade-off between finding employment quickly and attaining a better position.

Overall, the results indicate that origin-country human capital is devalued in the Swedish labour market. Immigrants can, however, get their previous knowledge and skills recognized, complemented with domestic human capital, and put to productive use after immigration. Nevertheless, achieving labour market outcomes either on par with the pre-immigration level or with comparable natives appears difficult for most.

Keywords: International migration, Immigrants, Labour market integration, Human capital 



\section{Acknowledgement}

I want to first and foremost thank my supervisors Zoran Slavnic and Moa Bursell. You have been with me through the ups and downs of my PhD studies. Always willing to help. Always having my best interest at heart. This dissertation would not have been possible without you.

I also want to thank my fellow PhD students at REMESO. Sara Ahlstedt, Indre Genelyte, and Karin Krifors who introduced me to the academic environment when I was new. Lisa Karlsson Blom and Julia Willén, for critical reflections, emotional support, and laughs throughout the years.

The friendship of Olav Nygård has been invaluable. I am so grateful for your insights into life, academic and beyond, and for your willingness to always share your knowledge and support everyone around you. I am beyond lucky to have had you as my closest colleague.

My co-author for Study I, Carina Hellgren, and her team at the Swedish Council for Higher Education enabled my first peer-reviewed publication to become better and more interesting than I could ever have imagined. I am thankful for the cooperation and the possibility to work with exceptional data.

I had the privilege of visiting Irena Kogan at the University of Mannheim as a guest PhD student. Your combination of kindness and analytical brilliance is an inspiration. Thank you for letting me visit and for the continued support.

I am thankful for the constructive feedback by the readers of my manuscript at the different grading seminars. Pieter Bevelander, Karen Haandrikman, Chaim La Roi, Anders Neergaard, and Ognjen Obucina, thank you for the many helpful comments you provided.

Martin Hällsten has read and commented on my texts, answered detailed questions about statistical coding, and been a general guide to the world of academia. I am truly thankful for all the time and attention that you dedicated to me.

A special thank you to Carolin Schütze who has provided feedback on manuscripts and fun company at conferences.

The administrative staff at REMESO are tremendously supportive, always taking the time to help stressed and confused PhD students. I want to especially thank Eva Renholm for her assistance with a countless number of administrative tasks over the years.

Scientific conferences have become a major interest of mine. The financial support from Helge Ax:son Johnsons stiftelse, The Lars Hierta Memorial Foundation, The Royal Swedish Academy of Letters, History and Antiquities, and the Norrköping stipend have made it possible to get 
feedback on my texts from international scholars, listen to exciting presentations, and expand my academic network. For this I am grateful.

During the last year of writing the dissertation I have had the fortune to get involved with new projects at the Institute for Futures Studies and Uppsala University. I would like to thank the principal investigators of these projects, Pontus Strimling and Birgitta Essén, for the opportunity to take part in some fascination research and for your patience with me during the last stressful dissertation-writing time.

I am immensely thankful for my family, Anatoli Tibajev and Natalie Falkman, for their support, love, and inspiration.

Finally, I want to thank Frida Gumpert Herlofson, Johanna Hohl, and Emelie Martinell. Writing this dissertation has not been easy, especially during the pandemic. Thank you so much for being there, making life a little less dull and a little more swinging.

Stockholm, December 2021

Andrey Tibajev 


\section{List of papers}

This dissertation is based on studies detailed in four papers, referred to in the text by the following Roman numerals.

I. Tibajev, Andrey \& Hellgren, Carina. (2019). The Effects of Recognition of Foreign Education for Newly Arrived Immigrants. European Sociological Review, 35(4), 506-52.

II. Tibajev, Andrey. The Economic Return to Labour Market Experience of Immigrants in Sweden. Submitted to Comparative Migration Studies.

III. Tibajev, Andrey. (2019). Linking Self-Employment Before and After Migration: Migrant Selection and Human Capital. Sociological Science, 6, 609-634.

IV. Tibajev, Andrey. Immigrants' Occupational Mobility in Sweden: The Value of Time. Submitted to International Migration Review. 



\section{Table of Contents}

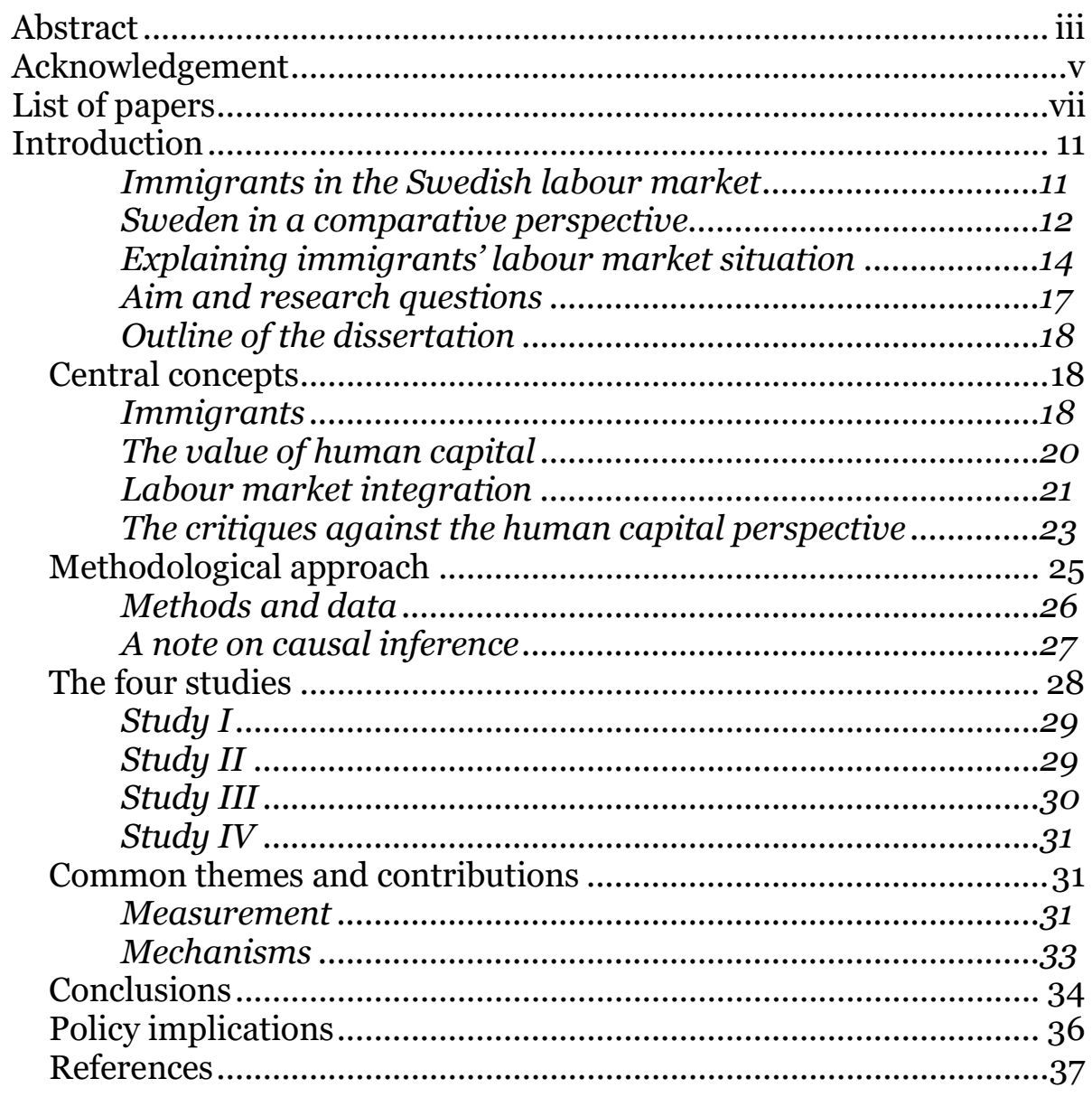





\section{Introduction}

Twenty per cent of the Swedish population is foreign-born. Approximately two thirds of these individuals immigrated as adults (Statistics Sweden, 2021). These individuals come from different countries, for different reasons and exhibit a great heterogeneity regarding life experiences, capabilities, and goals. The incorporation of the foreign-born population across different domains cannot, because of its size and heterogeneity, in any way be considered as a narrow endeavour. Instead, it is central to the function and cohesion of society (Portes \& Vickstrom, 2011).

Immigrants' possibilities to fully participate in the labour market are key to their incorporation. Having employment is connected to success in other domains of incorporation (Ager \& Strang, 2008). It is closely linked to poverty (Kesler, 2015; Obucina, 2013), the need for social assistance payments (Barrett \& Gustafsson, 2013; Bergmark \& Bäckman, 2004), health (Bask, 2005), life satisfaction (Kogan et al., 2018), and childbearing among women (Andersson \& Scott, 2005). This is the reason to study labour market integration-how immigrants fare in the domestic labour market, what processes that are behind the outcomes, and how policy can improve or impair their situation.

\section{Immigrants in the Swedish labour market}

There has been a clear gap in Sweden for the past 30 years in labour market participation, employment, and unemployment rates between immigrants and natives in favour of the latter group (OECD, 2021). In addition, employed immigrants are, on average, at a disadvantage in terms of both occupational position (Helgertz, 2011) and income (Hammarstedt, 2003) compared with their native counterparts. This situation has, however, not always been the case. Immigrants have gone from being on par, or even surpassing natives in labour market outcomes, to be at a clear disadvantage over time (Ekberg \& Hammarstedt, 2002; Gustafsson \& Zheng, 2006; Hammarstedt \& Shukur, 2006).

This change is in part connected to new migration patterns. In the post-war era, immigration was dominated by labour migrants, while family and refugees started increasing in the 1970s, accompanied by a shift in origin countries from closer to further away (for similar development in Western Europe, see Castles et al., 2014; Lundh \& Ohlsson, 1999; Nilsson, 2004). Labour migrants were either recruited abroad, coming to existing employment, or at least migrated specifically because of a perceived better opportunity to succeed in the new labour 
market (Grönberg et al., 2015; Rooth \& Saarela, 2007; Svanberg, 2011). Simultaneously, the increased distance of countries of origin implied that the newer cohorts were at a disadvantage regarding language and knowledge about the Swedish society (Helgertz, 2010).

Changes in the Swedish labour market and society have affected the ability to incorporate newly arrived individuals as well. One change is the overall higher unemployment rate that started in the 1990s. Immigrants, in Sweden (Gustafsson \& Zheng, 2006; Åslund \& Rooth, 2007) and abroad (Kogan, 2004; Panichella, 2018), are more susceptible to downturns in the economy and the labour market. A shift in the economy towards a constantly higher unemployment rate will therefore affect the gap between immigrants and natives. As expected, the economic downturn in the 1990s especially affected immigrants (Arai \& Vilhelmsson, 2004; Bergmark \& Palme, 2003).

Sweden has also shifted its economic structure and mode of production from an industry economy to a service economy, driven in part by the offshoring of industrial manual labour and long-term occupational upgrading (Härkönen \& Bihagen, 2011; Oesch \& Piccitto, 2019). Labour and industry jobs on the one hand and service jobs on the other premiere different skills, with the latter having a greater emphasis on communicative and social skills (Ulfsdotter Eriksson \& Backman, 2014). The shift has, therefore, led to increased problems for immigrants, since the newly arrived have fewer of these skills in contrast to technical knowledge, as the latter skills are more specific to the national setting (Bevelander, 1999, 2005; Rosholm et al., 2006).

\section{Sweden in a comparative perspective}

Sweden has, in comparative perspective, a labour market that is relatively open to immigrants, and comprehensive support systems and integration programs (Solano \& Huddleston, 2020; Valenta \& Bunar, 2010). This reception context is connected to the Swedish policy path focusing on immigrants' socio-economic integration (Borevi, 2014; Larsson, 2015). But there is a clear gap between policy intentions and labour market outcomes (Wiesbrock, 2011). Compared with other OECD countries, Sweden has a rather low employment rate for immigrants, and among the largest gaps between immigrants and natives (OECD, 2021). Comparing unemployment or participation rates yield the same results.

International comparisons of immigrants' labour market outcomes are hard to do since they must account for relevant differences between countries regarding the migrant population and how these differences interact with migration policy, labour market structure, and the welfare regime. Migration policies affect migrant selection by imposing restrictions or selection criteria (Aydemir, 2009; de Haas et al., 2018; 
Tani, 2019). Immigrants can also self-select into specific countries based on network ties (de Haas, 2010; Massey et al., 1993), or perceived benefits of a country's labour market and welfare system (Cebolla-Boado \& Miyar-Busto, 2019; Razin \& Wahba, 2015). Indeed, countries with more restrictive policies and countries with more positively selected, i.e., higher-skilled, immigrants display better labour market results (Birgier et al., 2018; Damelang et al., 2021; Haberfeld et al., 2020; Helbling et al., 2020).

Comparative research that tries to account for differences in migrant populations show a slightly more positive picture for Sweden's relative success regarding immigrants' labour market outcomes. Specifically, when studying the employment probabilities and the wages of family migrants and refugees, Sweden is on par with other countries (Bevelander \& Pendakur, 2014; Brell et al., 2020).

Though there is no one grand narrative that can explain all crosscountry differences (Alba \& Foner, 2014), and the number of theoretical explanations and statistical controls can fast exceed the number of included countries, some stable results have emerged in the comparative literature. First, a labour market with few unskilled or low-skilled occupations is detrimental to immigrants' labour market employment chances but favourable for their occupational attainment (Kogan, 2003, 2006; Pichler, 2011; Platt et al., 2021). Second, a compressed income structure reduces the immigrant-native income gap since there is less room for overall variation (Haberfeld \& Lundh, 2014; Kesler, 2010). Third, that general institutional arrangements surrounding the labour market and welfare system do not matter very much for immigrants' labour market success (Damelang et al., 2021; Platt et al., 2021), but integration support systems can favour those in most need, i.e. family migrants and refugees (Kanas \& Steinmetz, 2020).

An additional regard in which Sweden, together with the other Nordic countries, stands out internationally is the immigrants' female labour force participation. On the structural side, Sweden has a high overall female labour force participation and a welfare system that assumes dual-income households (Oláh \& Bernhardt, 2008; Oláh et al., 2018), accompanied by a self-perceived national culture of gender egalitarianism and consequently a special targeting of foreign-born women for labour market interventions (de los Reyes, 1998; Larsson, 2015; Towns, 2002). These gendered employment and integration policies have however increased female immigrants labour force participation and employment (Bevelander \& Pendakur, 2014; Kanas \& Müller, 2021; Kesler, 2006) and reduced immigrant poverty (Kesler, 2015). 
In summation, Sweden has a more challenging point of departure to incorporate immigrants in the labour market because of the substantial proportion of family migrants and refugees. The country's high-skilled labour market structure implies a trade-off with higher unemployment but better occupational attainment for immigrants. In contrast, the compressed income structure minimizes income differences between immigrants and natives. Employee protection regulations and the welfare system does not seem to matter much for immigrants' labour market results, but the extensive support systems aid family migrants and refugees. Finally, Sweden's high female labour force participation affect immigrant women, immigrant women, resulting in better labour market outcomes than other countries.

\section{Explaining immigrants' labour market situation}

Besides factors relating to structural features of the receiving context, the previous literature has several theoretical explanations for immigrants' labour market situation. These factors are considered more or less universal, i.e., they matter regardless of context.

One such explanation is connected to individuals' productive knowledge and skills, i.e. their human capital (Becker, 1962). The labour market is structured based on specialisation and hierarchy, meaning that different occupations require different knowledge and skills, and some occupations require more than others (Blau \& Duncan, 1978; Kalleberg \& Sorensen, 1979; le Grand \& Tåhlin, 2013). Having a specific set or level of human capital will, therefore, affect an individual's possibility of succeeding in the labour market. An additional dimension for immigrants is that human capital does not perfectly transcend national contexts, so that the knowledge and skills that immigrants bring with them from before immigration will be less valued in the domestic labour market compared to knowledge and skills acquired after arrival (Chiswick, 1978; Friedberg, 2000).

Studies focusing on immigrants' human capital have consistently produced empirical results in line with the expectations of this perspective. First, immigrants with higher education, i.e., more human capital, have better labour market results (Irastorza \& Bevelander, 2021; van Tubergen et al., 2004). Second, that the country-specific nature of human capital makes foreign education and labour market experience less valued than domestic (Chiswick et al., 2005; Duvander, 2001; Zeng \& Xie, 2004). Third, because of the country-specific nature of human capital, newly arrived immigrants experience a worse labour market position than they had in their country of origin and compared to natives with the same overall level of human capital, but outcomes improve over 
time with new destination-specific human capital acquisition (Fellini \& Guetto, 2019; le Grand \& Szulkin, 2002; Lubotsky, 2007).

Social capital, understood here as consisting of social ties and group memberships through which the individual can access and mobilize productive resources (Coleman, 1988; Lin, 1999), is a second explanation of the immigrants' labour market situations. Social capital matters because it affects the individual's ability to use human capital by providing information about and giving access to employment opportunities (Granovetter, 1974), and to make claims on labour market rewards through group resource mobilization (Tilly, 1998; TomaskovicDevey et al., 2015). Social capital can also work as a compensation for low levels of destination-country specific human capital (Aldrich \& Waldinger, 1990; Kalter \& Kogan, 2014; Seibel \& van Tubergen, 2013).

Empirical research with this focus has for example, shown that immigrants using informal job search methods have worse labour market outcomes than comparable natives, interpreted as happening because of the immigrants' lower amounts of social capital (Behtoui, 2008; Kracke \& Klug, 2021). It is also common to differentiate between social contacts with other co-ethnics or other immigrants, and social contacts with natives, i.e., between bonding and bridging social capital. It is primarily bridging social capital that has positive relationship with labour market outcomes (Kanas et al., 2012; Lancee, 2010, 2016).

As noted in the previous section, migrant selection is an important aspect of understanding labour market outcomes and is, thus, a third type of explanation. One key variable on which selection occurs is the reason for migration, often measured as the formal ground for residence. Generally, economic migrants perform the best in the new labour market, with family migrants next, and refugees have the hardest time (Bevelander, 2011; Zwysen, 2019). Immigrants with different migration reasons have differences is their ability to use origin-specific human capital. Since economic migrants are either chosen by domestic employers or choose a destination country based on perceived benefits, it is easier for them to utilise their knowledge and skills upon arrival compared with immigrants who came for other than economic reasons (Luik et al., 2016). A mitigating factor for family migrants compared with refugees is that the former has, by definition, someone they know in the destination country before arrival, someone who can help with initial knowledge about the society and the labour market.

Other key variables in migrant selection are age at immigration, with younger migrants assumed to be better equipped to acquire destinationspecific human capital and adopting the majority culture (Böhlmark, 2009; Schaafsma \& Sweetman, 2001), and gender, because men and women are sorted into different segments of the labour market (Lutz, 
2010; Schrover et al., 2007). Finally, a recent turn in the empirical literature is the study of migrants' relative position in the origin country, and how it affects outcomes in the destination (Feliciano, 2020; Schmidt et al., 2021). Immigrants who had a better educational or occupational position relative the origin population, are regardless of their absolute position assumed to have more actual skills and more motivation to reach higher positions after immigration.

A fourth explanation is discrimination. The competitive labour market is assumed, normatively and empirically, to work according to meritocratic principles. Individuals are to compete and have their market situation determined by productive factors such as human capital. When they instead are evaluated and have their life chances affected by factors nor relevant for productivity, but factors based on stereotypical thinking and stigmatisation, it is discrimination (Bursell, 2012a).

Discrimination in the labour market has traditionally been studied in two ways. One method is the so-called residual approach. An empirical analysis controls for productivity-relevant factors and if there is still a difference in the labour market outcomes between e.g., immigrants and natives, then the reason is probably in part because of discrimination (Midtbøen, 2015; Rydgren, 2004). Commonly, these controls include demography, human capital, and duration of stay in the destination country (e.g. Arai \& Vilhelmsson, 2004; Bask, 2005; le Grand \& Szulkin, 2002). An alternative is to control for a more direct measure of skill level through results on tests (e.g. Nordin \& Rooth, 2009). All the studies cited here find differences between immigrants and natives and suggest discrimination as a possible explanation.

The problem with the residual approach is that there is always a possibility of some unmeasured or unknown missing variable, and the inclusion of that variable would diminish the labour market outcome gap (Bursell, 2012a). Discrimination is therefore also studied with experimental methods, such as correspondence tests, where the researcher depends on random variation of the key explanatory variable rather than the inclusion of all possible relevant factors. Experimental evidence suggests that there is ethnic discrimination in Sweden (Arai et al., 2016; Bursell, 2014; Bursell et al., 2021) and abroad (Quillian et al., 2019; Zschirnt \& Ruedin, 2016).

A fifth explanation of immigrants' labour market position is selfemployment. Individuals enter self-employment because of promising economical gains (Evans \& Jovanovic, 1989), to escape a difficult situation on the regular labour market (Clark \& Drinkwater, 2000), or because of economic restructuring where employment relations are informalized and transformed to self-employment (Slavnic, 2010). 
Immigrants may also use ethnic social capital to mobilize resources for self-employment or cater to specific ethnic niches (Borjas, 1986; Light, 1984).

There is a large variation in immigrants' self-employment rates across origin and destination countries (Andersson et al., 2013; Hout \& Rosen, 2000; van Tubergen, 2005). In Sweden, self-employed immigrants are economically worse off than their native counterparts and employed immigrants (Andersson Joona, 2011; Hjerm, 2004). Explanatory factors for immigrant's lack of entrepreneurial success include that enter selfemployment out of necessity rather than choice and because they lack important resources such as (country-specific) human capital and social capital (Aldén et al., 2021; Van Der Sluis et al., 2008; Wauters \& Lambrecht, 2008).

The explanations above consider different aspects of the individual, social relationships, and structure, but they are complementary and intertwined, as this review has shown. Choosing one set of explanations as a focus does not automatically imply a disregard for the others. On the contrary, understanding how the variables and relations of interest in the different explanations affect each other and how they correlate with important demographic and contextual factors is key to understanding whichever explanation is chosen as the theoretical focus. Castles (2010, p. 18) argues that "to understand the regularities and variations" of migration, the phenomena should be studied with multiple theories of the middle-range. The argument here is that the same is true for the study of incorporation of immigrants into the labour market of the destination country.

\section{Aim and research questions}

This dissertation uses human capital theory as its point of departure, Specifically, the perspective of country-specific human capital, linking immigrant labour market integration to the less-than-perfect ability of human capital to transcend national contexts. This approach implies a dual focus on foreign and domestic human capital, connected to the two perceived main processes that affect immigrant labour market integration: a weak labour market position in the beginning because of the devaluation of foreign human capital and a gradual improvement with the duration of stay as the individual acquires new human capital specific to the destination country.

The aim of the dissertation is to study the human capital that immigrants bring with them from before immigration as well as the human capital that they acquire in Sweden. To analyse how it is being used and valued in the Swedish labour market and examine how this affects labour market outcomes. 
This dissertation contains four research questions connected to the aim, spanning over four different domains of the labour market: education, employment, self-employment, and occupational position. Each research question is answered in four self-contained studies.

1. Is there an effect of formal educational recognition on labour market outcomes?

2. What is the economic return on immigrants' labour market experience?

3. Does the experience of self-employment before immigration increase the propensity to become self-employed in the destination country?

4. What does the immigrants' occupational mobility look like across the migration event?

\section{Outline of the dissertation}

The following section in this introductory chapter examines the central concepts used in the dissertation-immigrants, human capital, and labour market integration. It discusses the main critique against the human capital perspectives in integration studies. The next section briefly examines the quantitative methodology used in this dissertation. The four independent studies are then summarized. Finally, the last three sections consider the contributions and conclusions drawn from this dissertation and reflects on policy implication. After this chapter, the four self-contained studies follow.

\section{Central concepts}

As the title reveals, the three central concepts for this dissertation are immigrants, human capital, and labour market integration. This section presents them and concludes with a critical discussion on the chosen theoretical focus.

\section{Immigrants}

Central to this dissertation project is the definition of the concept of immigrants. The definition used throughout this dissertation and the four studies uses the act of international migration as its core. It follows the definition of the International Organization for Migration (2019, p. 103) of an immigrant as "a person who moves into a country other than that of his or her nationality or usual residence, so that the country of destination effectively becomes his or her new country of usual residence". 
In common discourse and political debates, the term immigrant can have other meanings. Instead of deriving its meaning from a demographic attribute, immigrants have as a category come to be described and understood based on an otherness and through processes of boundary-making and stigmatisation in relation to the majority population (Alba, 2005; Bursell, 2012b; Schierup et al., 2006).

Understanding how this stigmatisation and the discourse of defining migrants based on otherness affect labour market outcomes is key. However, defining an immigrant as a foreign-born person, and thus a native as a person born in the country of residence, is important when using the perspective of human capital. The dual focus on knowledge and skills acquired both before and after immigration fits with this definition precisely because it highlights the move from one national context and labour market to another. It makes it possible to study differences in how old human capital is valued and new human capital acquired by the individual and how, e.g., demography and discrimination, affects these processes. A different definition, which would include children of immigrants or only count immigrants from certain origins, would dilute this focus.

It is, however, clear that immigrants arrive from different countries of origin, and that this fact has implications for labour market outcomes. From a Swedish perspective, immigrants coming from the Nordic region have the best outcomes, followed by other Western countries, followed by the rest of the world, often with immigrants coming Middle East and North Africa and Sub-Saharan Africa faring worse (Aldén \& Hammarstedt, 2015). The pattern is similar in other Western countries (e.g. Buzdugan \& Halli, 2009; Delaporte \& Piracha, 2018; Kogan, 2006).

There is no consensus in how to understand the correlation between immigrants' countries of origin and labour market outcomes. In previous research, variation in outcomes across different origins have had several interpretations. From a human capital perspective, variation is seen as caused by differences in human capital transferability and quality across countries (Bratsberg \& Terrell, 2002; Friedberg, 2000; Kanas \& van Tubergen, 2009), by linguistic distance between the language in the country of origin that makes it either easier or harder to learn the destination-country's language (Helgertz, 2013; van Tubergen \& Matthijs Kalmijn, 2005), or because the origin-country language in itself is a more or less transferable skill to the context in destination (Chiswick \& Miller, 2012; Pendakur \& Pendakur, 2002). Economic literature emphasising migrant selection interpret origin-country effects as differences in return to human capital, i.e. income inequality in origin and destination countries, and the transaction costs of moving (Borjas, 1989; Chiswick, 1999; Grogger \& Hanson, 2011). According to political 
economy and dual labour market theory, immigrants are sorted into either the primary or secondary labour market segment depending on the position of the origin country in the global economy and in relation to the country of destination (Hollifield, 2004; Hudson, 2007; McDowell, 2009; Piore, 1979). It can also be argued that it is reason for migration and not origin that matters, with refugees from countries that have the weakest labour market results (Karlsson \& Tibajev, 2014; van Tubergen et al., 2004).

Perspectives focused on culture, view variations in origins as an operationalisation of cultural distance between immigrants and natives (Fossati et al., 2019; Lundborg, 2013), or differences in origin-country gender norms specifically affecting immigrant female labour force participation (Blau et al., 2011; Neuman, 2018). Studies in labour market discrimination perceive the differences as being caused by stereotypical thinking among employers, with more stigmatisation and discrimination towards immigrants from some countries rather than others (Quillian et al., 2019; Thijssen et al., 2021).

What is notable throughout all these explanations is that they, by and large, predict the same result: immigrants coming from Western countries will have the easiest time in Western labour markets, while immigrants from the rest of the world will have it the toughest. The choice of perspective will inform what explanations are prioritized, but in reality, it is empirically hard to distinguish between them.

\section{The value of human capital}

Human capital theory explains the differentials in the labour market by referencing different levels of productive knowledge and skills among individuals (Becker, 1962; Mincer, 1974). Individuals invest in their human capital by education and on-the-job-training, increasing their productivity and, theoretically, getting higher labour markets rewards. For sociology, which views the labour market as made up of hierarchically structured positions, there is an intermediate step where human capital sorts individuals across these positions based on individual skills and positional skill requirements, with the positions in turn connected to unequal labour market rewards (Blau \& Duncan, 1978; Davis \& Moore, 1945; Eriksson \& Goldthorpe, 1992; Tåhlin, 2007).

Human capital can, in turn, be divided into a part that is general for the entire labour market, and another part that is specific for the firm or occupation; thus being unequally valued across the labour market (Becker, 1962). Foreign human capital, can in the same way, become devalued in the domestic labour market (Chiswick, 1978; Friedberg, 2000). 
Previous literature provides three main processes behind this devaluation (overviews in Chiswick \& Miller, 2009; Lancee \& Bol, 2017). Some human capital is specific to the national setting where it was acquired, e.g., because of differences in languages, national education systems, or industry standards, leading to transferability issues so that immigrants have, in part, a mismatched content in their human capital compared with natives. Quality differences in human capital between countries may occur because of differences in education spending or economic structure, leading to an actual difference in the level of human capital given the same formal amount of education and labour market experience. Domestic employers may also screen out immigrants with foreign credentials because they do not know what kind of human capital foreign educational degrees and certificates represent. They, therefore, become hesitant to employ immigrants.

Besides the processes that devalue foreign human capital, immigrants are often restricted in their ability to use their knowledge and skills in the new country by legal barriers in labour market (Solano \& Huddleston, 2020) or occupational closure (Alecu \& Drange, 2019). This restriction affects their labour market outcomes because human capital has no labour market value if it cannot be put to productive use. Research within the human capital tradition must, therefore, also study variables from the other main explanations-such as legal or other barriers blocking immigrants from access to certain occupations, social capital through which information about job openings can flow, and discrimination that hinders employment or advancement-to fully understand how human capital is used and valued in the labour market.

\section{Labour market integration}

Originally termed assimilation, labour market integration was thought of as a one-way process where new cohorts of migrants and minorities would take up the mainstream language and cultural traits and become socially incorporated into the mainstream of the host society (Gordon, 1964). The concept was later developed, and Alba and Nee (1997) argue that this original account is overly simplistic in its one-sided view of adaption and a homogenous account of the mainstream, confounded socioeconomic and cultural assimilation, and ignored the relationship between minority groups. The original conception of assimilation relies on a mechanistic view of social cohesion. This view assumes that the diversity brought by immigration is in itself a threat, ignoring that social cohesion is upheld by state institutions and not individual homogeniety in a modern society (Portes \& Vickstrom, 2011).

For Brubaker-who criticized the original assimilation account for being normatively concerned with cultural, rather than socio-economic 
assimilation, implying a total conversion and absorption of minoritiesassimilation should instead be understood as a "normative and analytical concern with the nature and extent of emerging similarities in particular domains between populations of immigration origin and 'host' populations" (Brubaker, 2001, p. 535).

The view on labour market integration in this dissertation is inspired by the above perspectives in that it concerns socio-economic attainment, a process rather than an end-state, and the population rather than the individual. It follows the notion of Alba and Nee (1997) to focus on a definition where ethnic distinction, or in this case migratory experience, loses its relevance for determining life chances. Finally, it is attuned to the critique against methodological nationalism that immigrants must be compared to a relevant native population, not just national means (Wimmer \& Glick Schiller, 2003). Thus. the definition is labour market integration as a process in which immigrants reach equality with natives on relevant labour market outcomes net of human capital differences.

Two normative implications follow this definition. First, immigrants and natives can have different labour market outcomes as long these are grounded in differences in productivity, i.e., human capital. Because the definition views integration as a process, combined with the aspect of country-specific human capital, it must be considered normatively acceptable that there are differences net of human capital when immigrants are newly arrived, but becomes less so with the duration of stay. It also implies that the opportunity for human capital recognition and acquisition should be equal between the categories to not create artificial differences in the long run. Second, since immigrants are defined as foreign-born, this definition is not multi-generational, where their children's outcomes can compensate for inequality in one generation. Equality should be reached within a lifetime.

The native-born population, while being the point of reference in this study, is, of course, not homogeneous, and part of it is exposed to stigmatisation and discrimination based on earlier generations migratory experience (Anderson, 2019; Portes \& Zhou, 1993). Children of immigrants have their life-chances affected by their parents' origin (Andersson et al., 2018; Behtoui, 2013; Nygård, 2021). How they accumulate domestic human capital, how they use it and how it is being valued are research questions in their own right (Nygård, 2020). But for all intents and purposes, they do not start their work-life in Sweden with foreign human capital.

The dual focus of country-specific human capital fits here because the object of study is precisely how human capital is being used and valued, how the process of foreign human capital devaluation creates initial labour market gaps between immigrants and natives, and how the 
process of new acquisition decreases that gap. It promotes questions like why the devaluation initially happens, if there is a variation across origins, and how to best mitigate it. As well as questions about how immigrants acquire new human capital, what is the most important new human capital to acquire, and how their ability to use it is related to them being foreign-born?

\section{The critiques against the human capital perspective}

Human capital theory is not without its critiques (for overviews, see Sweetland, 1996; Tan, 2014). The critique discussed in this section is narrower in scope, with particular reference to country-specific human capital and labour market integration. It is divided into two main domains: methodological and normative.

Methodologically, human capital is viewed as residing within the individual. i.e., individuals invest in human capital, it increases their productivity, and in the final stage leads to increased labour market rewards. From both Marxist and sociological perspectives on the labour market, this conceptualisation ignores the social and structural conditions under which human capital is both acquired and transformed to productivity (Bowles \& Gintis, 1975; Sorensen, 1977; TomaskovicDevey et al., 2005). According to these perspectives, investments in human capital is not only the individual's decision, and productivity depends on the human capital's ability to be used within specific configurations of technical and social relations.

The inclusion of the labour market structure in the analyses, i.e., to differentiate between individual skills and occupational skill requirements, partly resolves this issue. The possibility to invest is onthe-job training is stratified in the labour market (Korpi \& Tåhlin, 2021). Research that simultaneously include wage effects of both individual and structural aspects has consistently shown that the skill requirements of the occupation that determines wage the most (Hartog, 2000; Korpi \& Tåhlin, 2009). In this dissertation, Studies I, II and IV explicitly discuss the connection between human capital and structure, assuming that human capital is primarily used to sort individual across labour market positions, and that these positions are, in turn, connected to investments and rewards.

There is additional depth to this problem when studying labour market integration. Some country-specific human capital-such as language, ability to communicate, or knowledge about behavioural codes and customs-is intrinsically social. That is, the skills are both socially constructed and receive their value in social interaction (Irvine, 1989; Urciuoli, 2008). The right way of communicating or being creative in a 
specific organisational setting does not reside within one individual, but between all individuals in that organisation. However, nationalist discourses about immigrants' lack of cultural compatibility with natives-framed in the language of human capital-places the responsibility for acquiring these skills on immigrants (Siebers, 2018). Simultaneously, employers connect ethnic categorisation to these soft skills, defining ethnicities in terms of competencies (Friberg \& Midtbøen, 2018; Moss \& Tilly, 1996).

Consequently, there is no clear boundary between the human capital of the individual immigrant on the one hand, and categorisation, exclusion, and discrimination by others on the other. Since job performance is not only appraised on what is done but also how it is done (Ulfsdotter Eriksson et al., 2020), immigrants are at a disadvantage when the evaluation includes social soft skills (Siebers \& van Gastel, 2015).

The result is that the devaluation of human capital does not only happen because the skills and knowledge are foreign, but also because the individual inheriting them is. Labour market integration can, therefore, not be examined from a human capital perspective without also considering the larger societal context and discrimination. Research that analyses how human capital valuation is connected to immigrants' origin or gender has, by and large, confirmed the connection. For example, enhancing the CV with engagement in an ethnic cultural association helped Spanish but harmed Turkish immigrants in Switzerland (Fossati et al., 2019), and enhancing a CV with more experience did reduce discrimination for foreign women but not men in Sweden (Arai et al., 2016). All included studies in the dissertation regard for this critique by considering the context of reception as well as unequal human capital valuation for different migrant categories.

The normative critique against country-specific human capital is mainly a critique of when these considerations are not given, e.g., when the concepts of human and cultural capital are confused, a hierarchy based on origin is taken for granted, and discrimination ignored.

In a Swedish context, this critique has been the most strongly formulated by Mattsson (2001) who names this research perspective the discourse on lack of competence (Swedish: kompetensbristdiskursen). Mattsson's argument is that this discourse is an expression of cultural racism because it uses culturally contingent competencies to explained labour market differences between immigrants and natives. Competences that are viewed as being a natural part of individuals from different origins and hierarchically structured based on the notion of cultural distance. Culture, used as a floating signifier in this discourse, creates a situation where immigrants are both seen as naturally different, 
and simultaneously become responsible for adopting the majority culture. In other words, a critique against empirical studies that adopt a container model of society, viewing everything outside the nation-state as analytically distinct (Wimmer \& Glick Schiller, 2003).

A normative focus on individuals taking responsibility for their own integration process by investing in themselves, instead of it being a societal endeavour, is a reflection of a turn toward "neoliberal disciplinary strategies" (Schierup \& Ålund, 2011, p. 56). The problem is that a view of individual human capital accumulation, or acculturation, as the main strategy for labour market integration, with some failing in that strategy because of how they get categorised, creates a risk of blaming the victim (Siebers, 2018).

Mattsson (2001) argues that this discourse excludes employers from any responsibility, portraying the discrimination of immigrants as economically rational and neutral behaviour. At the policy level, this perspective leads to a normative view of immigrants being suited for specific types of occupations-manual, routinised, isolated-and the political solutions that become relevant are to increase the number of unskilled jobs or to increase income inequality. In the same vein, discrimination is thought to be solved with more information about immigrants' productivity (de los Reyes, 2000).

The studies included in the dissertation are trying to distinguish between human capital and the more problematic use of cultural capital as an explanation. In Study III, the idea of homogenous origin cultures is explicitly criticised. It is possible to study labour market integration as an empirical phenomenon while simultaneously being critical how the term is being used normatively in public discourses (Penninx, 2019). Similarly, and in contrast to Mattsson's argument, it is possible to use the perspective country-specific human capital and simultaneously consider labour market integration as a societal endeavour. Some policy recommendations born out of this dissertation are discussed in the final section.

\section{Methodological approach}

Following the definition of labour market integration, the interest at hand is to study whole populations rather than individuals. Quantitative methodology is the appropriate choice when the object of study is probabilistic regularities on the population level (Goldthorpe, 2015). This section presents methods and data and contains a discussion on the assumptions behind the causal interpretations of two of the included studies. 


\section{Methods and data}

All four studies make use of statistical data and different regression techniques. The Swedish Council for Higher Education provided data for Study I. It consisted of all immigrants who got a recognition statement at the agency in 2007-2011 and was matched with administrative population-level data on migration and labour market outcomes, the latter for the years 2005-2012. A total of 12,792 individuals were included in the study.

Studies II-IV use the Level-of-Living Survey for Foreign-Born and Their Children (Migrant-LNU), a companion survey to the Level-ofLiving Survey 2010 (LNU2010), which is also used in Study I. Data was collected 2010-2012 by Statics Sweden using a combination of computerassisted personal interviews and computer assisted telephone interviews. If the respondents requested it, Statistics, Statistics Sweden provided an interpreter during the interview.

Migrant-LNU has two exceptional advantages compared to other similar surveys in Sweden and other countries. First, it is representative of the adult immigrant population- defined as all foreign-born with foreign-born parents, aged 18 and older and who lived in Sweden for at least five years-and it promotes comparison among immigrants of different origins through its stratified sample technique across seven regions of origin times three age groups. Second, it is comprehensive and high-quality. Relevant to the studies at hand, Migrant-LNU contains an employment biography that includes all labour market activities of its respondents, including the start and end dates for those activities. This information makes it possible to measure labour market experience from before migration (Studies II) and construct retrospective panel data (Studies III and IV). The total response rate for Migrant-LNU was 49 per cent, or 3,448 respondents. More information about the Level-of-Living Surveys can be found at the Swedish Institute for Social Research (2017).

Though the concept of immigrant is defined as a foreign-born individual in the dissertation, actual, analytical, samples are guided by each specific research question and vary across the studies. In Study I, the focus is on a specific policy effect, and the sample is thus further limited in time and only includes immigrants affected by the policy. For the studies using Migrant-LNU, two additional sample restrictions are in place. Only working-age immigrants are included in Studies II and IV because the study designs use current labour market status as the dependent variable. In Studies III and IV, only immigrants who arrived in Sweden from the age of 18 are included to ensure that everyone could have obtained foreign human capital before immigration. 


\section{A note on causal inference}

Two of the included studies, I and III, make causal claims. The view on causality is here foremost inspired by the notion that causal explanations must always be grounded in theoretical arguments (Blossfeld et al., 2007; Goldthorpe, 2000). In particular, there is a tendency in the studies towards so-called mechanism-based explanations.

There is no one clear definition of what a social mechanism is, but what is common to most definitions of mechanism-based explanations is that they make explicit statements about the link between cause and effect with a reference to social action (Elster, 1989; Gross, 2009; Hedström \& Ylikoski, 2010), together with a methodologically individualistic foundation and a Weberian understanding of why actors do what they do (Edling \& Rydgren, 2016). The studies that make causal interpretations have a tendency towards more economistic, rational choice, perspective in their assumption about human behaviour. In Study I, it is primarily that employers are risk-averse profit-maximisers. In Study III, immigrants will choose the most profitable path in the labour market given their previous experiences and current labour market status. This result is undoubtedly a consequence of the choice of human capital theory as the main perspective and the setting of the competitive labour market.

For the methodological part of causality, inspiration is drawn from the counterfactual paradigm (Study I) and the life-course perspective (Study III), respectively.

The counterfactual mode of thinking is to set up a research design that as closely as possible resembles an experiment with the randomised controlled trial as the benchmark (Angrist \& Pischke, 2015). Even with observational data, which the dissertation relies on, the key is to think about how to best mimic an experimental situation in a real-life setting. The reason for this approach is the fundamental problem of causality in social science, that units of observation can only be observed in one state. To be able to draw causal inference, i.e. for the counterfactual states to be an unbiased comparison, the selection between the two states must be as good as random (Morgan \& Winship, 2014).

Consequently, there is a discussion about the voluntary nature of selfselection into the intervention of formal educational recognition in Study I. The counterfactual paradigm makes two central assumptions when calculating the average treatment effect of an intervention, the control group would have the same average (counterfactual) effect of the treatment as the treated, and that the treated would have the same (counterfactual) baseline level of outcomes as the control group (Morgan \& Winship, 2014, pp. 60-62). Because of the voluntary nature of 
acquiring a recognition statement, there is a non-trivial possibility that immigrants who do acquire recognition are too different on e.g., motivation and other characteristics rewarded in the labour market, compared to those who can but do not. For that reason, Study I uses a design taken from Arai and Thoursie (2009), only including those who are treated and utilising an (as good as random) variation of the timing of recognition within each individual instead. This method estimates an average treatment effect on the treated only.

Study III relies on retrospectively created panel data to allow for the measurement of timing between different interdependent events. Specifically, how different events such as labour market experience, experience of self-employment, changes in partner status and going into and out of the regular labour market affect the probability of entering first self-employment. The main focus in this type of set-up is not random assignment but rather the ordering of events and changes in time, i.e. that the cause must come before the effect and that there must be some change at some point in time in the outcome to be able to reason in a counterfactual way and thus draw causal inference (Blossfeld et al., 2007, pp. 25-27). It can be noted that variables that themselves are timeinvariant, such as origin or gender, can still be included as causes in the analysis because what is important is the social construction surrounding these characteristics, and what social mechanisms connect them to relevant outcomes.

Since the design of Study III does not try to mimic random assignment and instead relies on control variables to measure an unbiased statistical relationship between self-employment before and after migration, it is possible to criticise it for having problems with omitted variable bias (Morgan \& Winship, 2014). In this case, the strongest critique against its causal claims would be that of self-selection into self-employment due to psychological traits. I.e., some individuals choose self-employment before and after migration because they prefer it, or some specific aspect of it (like freedom or risk). If true, it would mean that the positive correlation between self-employment before and after migration, which is the study's main result, is upward biased.

\section{The four studies}

The dissertation contains four research questions connected to the aim. Each research question is answered in one of four self-contained studies. 


\section{Study I}

Highly educated immigrants can have difficulty getting a foothold in the Swedish labour market because employers might be uncertain about the content or quality of their foreign degrees. To remedy this problem, the Swedish government offers recognition of foreign education, a sort of translation of foreign educational credentials into Swedish conditions. The first study, co-authored with Carina Hellgren, measures the labour market effect of this recognition procedure for all immigrants who got recognition for non-regulated academic professions during 2007-2011, using population-level registry data.

Analyses using fixed effects regressions show that there is a positive effect of recognition of foreign education. Immigrants are both more probable to have employment and have higher wages after recognition. Analyses also show that the effect of recognition is concentrated at the lower end of the income distribution, i.e., that recognition is better at getting immigrants into the labour market and less so helping them to get a high-paying, presumably academic, job. Additionally, the effect varies with different immigrant categories such as origin, the reason for immigration, and recognition year. Immigrants from EU15+ and Eastern Europe experience larger effects than immigrants from Africa, Asia, and Latin America. This fact is interpreted as that employers' value of human capital from the former regions is higher. Family migrants, compared to refugees, and those who acquired recognition during good economic years, experienced larger effects, suggesting that there is an interaction between the value of a recognition statement and the ability to use it in the labour market. The results point together toward a complex interplay between different economic and social processes in the labour market. When employer uncertainty is reduced, other issues of human capital transferability become more salient.

\section{Study II}

The second study focuses on the value of immigrants' labour market experience, both before and after immigration. Following the dual focus of the approach of country-specific human capital, the study's research questions are as follows. First, what is the return to immigrants' labour market experience before immigration, and does it vary with origin? Second, what is the return to immigrants' labour market experience in Sweden, how does it compare to natives' return, and does it vary depending on whether immigrants acquired destination-specific human capital before or after labour market entry?

The regression results show that only pre-immigration labour market experience from the Nordic countries have a positive return in the labour 
market. In contrast, experiences from the other origins have, on average, zero association with the current wage. This support explanations of transferability problems of human capital caused by the institutional distance between the labour markets, i.e., that closeness of the Nordic region helps human capital to travel across national contexts. The results also show that return to labour market experience after immigration does not depend on whether the individual acquired Sweden-specific human capital before or with the entry into the labour market. Natives and immigrants and immigrants with and without schooling or upbringing in Sweden have parallel wage trajectories across labour market experience years, with immigrants being at a stable disadvantage. This disadvantage is interpreted to be caused by immigrants being sorted into jobs with worse opportunities to acquire new human capital compared with natives.

\section{Study III}

Self-employment can be a viable labour market strategy for immigrants, either because of special talents and a network that native-born do not have access to or escape unemployment and hardship in the regular labour market. It has always been acknowledged that there is a large variation across different immigrant categories regarding the propensity for self-employment after immigration, and different hypotheses have been put forward to explain this variation. One of these has been to link experience of self-employment before and after migration. The third study examines this link by testing the so-called home-country selfemployment hypothesis, the idea that individuals who have been selfemployed in the past have accumulated a specific entrepreneurial human capital, making them more likely to become self-employed again. This hypothesis is prominent in previous research and tested in several settings, but with overall detrimental results. The issue has been argued in this study that previous research has relied on country-of-origin average rates of self-employment to approximate, individual experience before migration, ignoring the problem of migrant selection.

Using the employment biography in Migrant-LNU first shows that the hypothesis previously been empirically tested by approximating immigrants' individual experience with the average self-employment rate in their respective origin country is the reason for the failure. Migration is not a random process, and immigrants are not representative of their origin populations. Second, analyses using Cox regression models show that immigrants who have been self-employed before immigration have almost twice as high propensity for selfemployment in Sweden compared to those who previously only been wage employed. The conclusion is that there is a strong link between self- 
employment before and after migration, but it can only be measured on the individual level.

\section{Study IV}

On arriving in a new country, immigrants generally enter the labour market in a worse occupational position than they held in their country of origin because of the less-than-perfect transferability of human capital. As they later acquire new destination-specific human capital, they also experience a subsequent, albeit partial, upward mobility. Together, these processes create a mobility pattern of a stalled U-shape. Study IV explores immigrant occupational mobility in Sweden and examines if there is a trade-off between finding employment quickly and attaining a better position.

Results show that the overall occupational mobility pattern follows the international trend of a stalled U-shape-immigrants coming from higher occupational positions in the origin country experience the largest downward mobility upon arrival. Results also show that there is indeed a trade-off: a longer time until employment both mitigates the initial downgrade and facilitates the subsequent upgrade in occupational status. The strongest positive correlation between time and labour market position is found among immigrants with the largest initial occupational downgrade. In these cases, individual pre-migration human capital and the Swedish labour market structure work in tandem, leading to the most favourable result.

\section{Common themes and contributions}

Two themes span over the included studies: measurement of human capital and mechanisms behind labour market outcomes. These are the two main overarching contributions of the dissertation to the field of labour market integration.

\section{Measurement}

A central problem for all quantitative social science is operationalisation, i.e., the definition and measurement of analytical concepts. In migration and integration studies, this problem is accentuated. First, the data at hand is often of lower quality or even absent for migrants, especially for time before immigration to the new country. Second, the line between analytical categories and subjective groups are not always that clear and there is an inherent power dynamic in the act of research. Not only is the researcher in a privileged position in relation to the object of research, but both the category of migrant and the different subcategories such as 
origin or ethnicity, are socially constructed, based in policy and history (Simon \& Piché, 2012) and measured with diverse national traditions (Jacobs et al., 2009). Thus, the act of creating analytical distinctions, i.e. of exaggerating differences between categories while simultaneously underrating intra-category heterogeneity (Zerubavel, 1996), may be illuminating for research by pointing to important differences between populations, but also reaffirming and upholding those differences.

Interestingly, there is a connection between bad data and overly generalising statements about (categories of) immigrants. The connection stems from migrant selection, the fact that migration is a selective process and thus that migrants are not representative of the population in their respective origins. When data on immigrants' individual experiences are absent, it is not uncommon to use categorylevel approximations based on country of origin in its place. This approach is empirically incorrect, because of migrant selection, and exaggerates the similarity within a group while at the same time masks individual heterogeneity. In other words, this practise confuses analytical categories and subjective groups by assuming shared experiences.

Study II contributes to the field by measuring labour market experience instead of assuming it. In the absence of data on individual labour market experience, a common practise is to use a so-called potential measure (e.g. Borjas, 1985; Chiswick, 1978; Friedberg, 2000). Potential labour market experience is the maximal number of years of work that the individual can have. This approximation might have been a reasonable approximation of actual labour market experience when the practise started, because the studied population was white males in the USA 1960 (Mincer, 1974), but when including populations that experience labour market uncertainties, it becomes flawed. Not only is there a variation between immigrants and natives, and immigrants with different origins or reasons for migration, regarding labour market attachment in the destination country. There is also an obvious error with using potential labour market experience for the time in the origin country. It is not hard to imagine that immigrants who migrate because of persecution or conflict were not able to fully use their potential time in the labour market, or that economic migrants moved to find better labour market opportunities. Assuming potential labour market experience is inaccurate both before and after immigration and will create bias when comparing categories with differences in labour market attachment.

Study III makes another contribution regarding measurement by showing that immigrants who come from countries with large selfemployment sectors are not more likely to have been self-employed 
themselves. This study explicitly shows how incorrect a category-level assumption can be because of migrant selection. By combining both individual and origin-level variables in the same model, the study does not only act as a cautionary tale of testing reasonable theory with bad data, but it also points to how wrong it can get when researchers superimpose cultural trait upon individual, in this case assuming that immigrants with a certain kind of origin are more entrepreneurial.

Study IV contributes by including the time it takes to gain employment, focusing on the trade-off between the duration and occupational position. Previous literature has pointed to the importance of time spent in the country of destination in general, and more specifically, how time is used and managed by immigrants during the first years after arrival (Fuller, 2018). Studying immigrants' occupational mobility without accounting for how long each occupational transition takes will both hide the diversity of different paths taken in the labour market, and risk missing some of the strategies that immigrants use to succeed.

\section{Mechanisms}

The second theme, and main contribution of this dissertation, is some of the mechanisms connected to human capital transferability.

Study I answers the question of why immigrants have a hard time using their education in the destination country. The reason is, partially, because of the mechanism of employer uncertainty. Based on signalling and screening theories (Spence, 1973; Stiglitz, 1975), educational credentials act as productivity signals for employers, having their own market worth besides human capital (Araki, 2020). If employers do not understand foreign credentials, they are hypothesised to avoid employing the immigrants who have those foreign degrees. Recognition of foreign education is a unique isolation of the mechanism of employer uncertainty because the recognition statement neither affects the content nor the quality of the foreign degree. Thus, the positive effect of the policy of recognition that Study I finds is also an indication of that the mechanism of uncertainty is real, because of the reaction to the policy by Swedish employers.

Another mechanism is highlighted in Study III. This time the issue is not why knowledge and skills have trouble transcending national contexts, but rather the opposite, how they can do it. The study focuses on the propensity for self-employment. It shows that immigrants who have been self-employed before immigration to Sweden also are more likely to enter first self-employment in Sweden. The mechanism at hand is that previous self-employment experience is coupled with the accumulation of human capital in running a business, called 
entrepreneurial human capital. This accumulation makes future selfemployment a more viable alternative. In choosing between wage employment and self-employment, individuals calculate the possible rewards versus the potential risk, especially if there is a need for an initial investment cost to start a business (Borjas, 1986; Evans \& Leighton, 1989). Having already been self-employed previously should influence both sides of that equation. Higher human capital implies knowledge and skill regarding what to do (higher rewards) and avoid (lower risk).

The interpretations of both mechanisms above are based in rational choice. But it is possible to interpret them in more general microsociological terms as being "more or less habitual responses" of individuals when facing new situations (Gross, 2009, p. 368). That is, employers prefer what is known to what is unknown, and previously selfemployed individuals engage in an activity they are familiar with in a new labour market

\section{Conclusions}

This dissertation studies the value and use of immigrants' human capital for labour market integration. It argues that labour market position is of key importance because it affects life-chances and outcomes in other domains. Integration-defined as the process in which immigrants reach equality with natives on relevant labour market outcomes net of human capital differences-is, therefore, a central part for the functioning of society.

The four research questions of the dissertation are answered in the four independent studies. The results are:

1. There is an effect of formal educational recognition, but it is concentrated in labour market entry rather than entry into qualified occupations and varies between different subcategories of immigrants.

2. The economic return to immigrants' pre-migration labour market experience is zero for all but Nordic migrants. The return is positive for experience in Sweden. However, not enough to catch up with the wages of natives.

3. Experience of self-employment before immigration almost doubles the propensity to become self-employed in the destination country.

4. Immigrants' occupational mobility across the migration event resembles a stalled U-shape, with a trade-off of gaining employment later and achieving a higher position. 
Overall, in line with previous research, the results indicate that origincountry human capital is devalued in the Swedish labour market. The size of the devaluation follows the expected pattern of variation across origin countries, the least for immigrants from Nordic and Western countries and more for immigrants from the rest of the world. Immigrants can, however, get their previous knowledge and skills recognized, complemented with domestic human capital, and put to productive use after immigration.

Viewed as a process, labour market integration occurs in Swedenlabour market outcomes for immigrants improve with the duration of stay, and the gap between immigrants and comparable natives is reduced. But the integration is not completed. Immigrants are sorted into worse labour market positions than comparable natives, and the mobility out of these positions is hampered by unequal possibilities to acquire new relevant human capital. Thus, achieving labour market outcomes either on par with the pre-immigration level or with comparable natives appears difficult for most immigrants. Interpreted through the lens of the residual approach to discrimination, it cannot be excluded that some of these remaining differences are the result of discriminatory practices.

Future research in the tradition of country-specific human capital should continue to improve the measures of immigrants' human capital and selection, closely study the processes and mechanisms that affect labour market integration and focus on the intersections where human capital and other explanations meet. Promising recent examples of such studies are on how more fine-grained migration motivations affect economic outcomes for migrants within the free-movement regime of EU (Luthra et al., 2018), how immigrants make their decisions on whether to invest in destination-country education (Damelang \& Kosyakova, 2021), and on the interplay of human capital, status, and gender in immigrant self-employment (Webster \& Haandrikman, 2020).

The argument of this dissertation is that the negative sorting of immigrants across stratified positions in the labour market is the main reason behind inequality between immigrants and natives. Immigrants become negatively sorted because their foreign human capital is devaluated, of barriers to acquire new human capital, and because immigrants are in different ways restricted to use their human capital. The limitation of the argument and the main conclusions is thus connected to this implicit causal chain linking origin, to sorting, to outcomes.

The concept of social stratification used is positional but not relational (Wright, 2009). The focus is on sorting across unequal positions, assuming that the inequality in positions is related to skill requirements, 
i.e., to the efficiency or complexity of job tasks, but not to the individuals occupying them. Inspired by the literature on the devaluation of female work (England et al., 2007; Karlin et al., 2002), a relational view on labour market integration could study how changes in origin composition across occupations affect status and wage, or how the cultural processes of stigmatisation and racialisation underpin stratification processes (Lamont et al., 2014). This would be fruitful avenues for future research.

\section{Policy implications}

As noted in the introductory section, structure, institutions, and policy affect labour market integration and comparative research shows that Sweden's open labour market and comprehensive support systems aid the most vulnerable immigrants. Additionally, research shows that labour market interventions can improve outcomes for its participants (Butschek \& Walter, 2014; Kluve, 2010; Qi et al., 2021). The same is true for changes in legal status such as citizenship acquisition (Bevelander \& Pendakur, 2012; Helgertz et al., 2014).

This final section contains policy implications, or recommendations, brought about from the country-specific human capital perspective's dual focus and the empirical results of the included studies. Like the rest of the dissertation, the four recommendations concern the valuation of immigrants' human capital and their ability to use it.

First, immigrants bring with them human capital that need to be assessed and recognized in order to be utilized (Lodigiani \& Sarli, 2017). Reitz (2001), for example, connects the deteriorating labour market outcomes for immigrants in Canada to a combination of increased education level among natives, increased significance of education in the labour market, and problems with immigrants' educational recognition. As noted, Sweden undergoes the same labour market restructuring and upskilling, and as Study I shows, credentials matter here as well. From a policy perspective, recognising formal credentials and skills so they can be readily used is also cheaper and faster than starting from zero. In this area, Sweden is among the most successful countries (Solano \& Huddleston, 2020).

Second, since domestic human capital is important in determining outcomes in the labour market, immigrants should have immediate and cost-free access to high-quality education and training. This policy should especially be the case if a political goal is to persist in being a highskilled economy.

Third, immigrants must have the best possible opportunities to use their knowledge and skills, including strong anti-discrimination 
measures and a general policy toward a low unemployment rate. The latter follows from the fact that immigrants are more vulnerable to weak labour markets compared with natives. Improving the overall labour market situation is therefore a way to reduce the immigrant-native gap in outcomes. As Hansen (2021) readily shows, investing in relation to migration is profitable for society, because it is productive capital, not money, that is the scarce resource.

Fourth, immigrants must be given the opportunity to make the best possible decisions regarding investment in and use of human capital, including stable living conditions in the form of the right to permanent residence and the ability to re-unite with family members. Perpetuating constant insecurity through restrictive migration laws creates precarity in labour market relations (Anderson, 2010; De Genova, 2002) and health problems for immigrants (Juárez et al., 2019). It may also push immigrants into segments of the labour market for which they are overqualified rather than promote investment in education (Jutvik, 2020), a labour market strategy that is sub-optimal if the goal is to attain highstatus occupations (Kogan \& Weißmann, 2013; Zhang \& Banerjee, 2021). The knowledge and skills that immigrants have are valuable to society, there is no reason to prevent them from being fully used.

\section{References}

Ager, A., \& Strang, A. (2008). Understanding Integration: A Conceptual Framework. Journal of Refugee Studies, 21(2), 166-191. https://doi.org/10.1093/jrs/fen016

Alba, R. (2005). Bright vs. blurred boundaries: Second-generation assimilation and exclusion in France, Germany, and the United States. Ethnic and Racial Studies, 28(1), 20-49. https://doi.org/10.1080/0141987042000280003

Alba, R., \& Foner, N. (2014). Comparing Immigrant Integration in North America and Western Europe: How Much Do the Grand Narratives Tell Us? International Migration Review, 48, S263S291. https://doi.org/10.1111/imre.12134

Alba, R., \& Nee, V. (1997). Rethinking Assimilation Theory for a New Era of Immigration. International Migration Review, 31(4), 826874. https://doi.org/10.2307/2547416

Aldén, L., Bastani, S., Hammarstedt, M., \& Miao, C. (2021). Immigrantnative differences in long-term self-employment. Small Business Economics. https://doi.org/10.1007/s11187-021-00462-z 
Aldén, L., \& Hammarstedt, M. (2015). Utrikes födda på 2000-talets arbetsmarknad - en översikt och förklaringar till situationen. Ekonomisk Debatt, 43(3), 77-89.

Aldrich, H. E., \& Waldinger, R. (1990). Ethnicity and Entrepreneurship. Annual Review of Sociology, 16, 111-135. https://doi.org/10.1146/annurev.so.16.080190.000551

Alecu, A. I., \& Drange, I. (2019). Barriers to Access?: Immigrant Origin and Occupational Regulation. Nordic Journal of Migration Research, 9(1). https://doi.org/10.2478/njmr-2019-0001

Anderson, B. (2010). Migration, immigration controls and the fashioning of precarious workers. Work, Employment \& Society, 24(2), 300317. https://doi.org/10.1177/0950017010362141

Anderson, B. (2019). New directions in migration studies: towards methodological de-nationalism. Comparative Migration Studies, 7(1). https://doi.org/10.1186/s40878-019-0140-8

Andersson, A., Edling, C., \& Rydgren, J. (2018). The intersection of class origin and immigration background in structuring social capital: the role of transnational ties. The British Journal of Sociology, 69(1), 99-123. https://doi.org/10.1111/1468-4446.12289

Andersson, G., \& Scott, K. (2005). Labour-market status and first-time parenthood: The experience of immigrant women in Sweden, 1981-97. Population Studies, 59(1), 21-38. https://doi.org/10.1080/0032472052000332683

Andersson Joona, P. (2011). The Native-Immigrant Income Gap among the Self-Employed in Sweden. International Migration, 49(4), 118-143. https://doi.org/10.1111/j.1468-2435.2009.00510.x

Andersson, L., Hammarstedt, M., Hussain, S., \& Shukur, G. (2013). Ethnic origin, local labour markets and self-employment in Sweden: a multilevel approach. Annals of Regional Science, 50(3), 885-910. https://doi.org/10.1007/s00168-012-0525-1

Angrist, J. D., \& Pischke, J.-S. (2015). Mastering 'metrics : the path from cause to effect. Princeton University Press.

Arai, M., Bursell, M., \& Nekby, L. (2016). The Reverse Gender Gap in Ethnic Discrimination: Employer Stereotypes of Men and Women with Arabic Names. International Migration Review, 50(2), 385-412. https://doi.org/10.1111/imre.12170

Arai, M., \& Thoursie, Peter S. (2009). Renouncing Personal Names: An Empirical Examination of Surname Change and Earnings. 
Journal of Labor Economics, 27(1), 127-147. https://doi.org/10.1086/593964

Arai, M., \& Vilhelmsson, R. (2004). Unemployment-Risk Differentials Between Immigrant and Native Workers in Sweden. Industrial Relations, 43(3), 690-698. https://doi.org/10.1111/j.00198676.2004.00355.x

Araki, S. (2020). Educational Expansion, Skills Diffusion, and the Economic Value of Credentials and Skills. American Sociological Review. https://doi.org/10.1177/0003122419897873

Aydemir, A. (2009). Immigrant selection and short-term labor market outcomes by visa category. Journal of Population Economics, 24(2), 451-475. https://doi.org/10.1007/s00148-009-0285-0

Barrett, A., \& Gustafsson, B. A. (2013). Social assistance among immigrants and natives in Sweden. International Journal of Manpower, $34(2)$,

126-141. https://doi.org/10.1108/01437721311320654

Bask, M. (2005). Welfare Problems and Social Exclusion Among Immigrants in Sweden. European Sociological Review, 21(1), 7389. https://doi.org/10.1093/esr/jci005

Becker, G. S. (1962). Investment in Human Capital: A Theoretical Analysis. Journal of Political Economy, 70(5), 9-49. https://doi.org/10.2307/1829103

Behtoui, A. (2008). Informal Recruitment Methods and Disadvantages of Immigrants in the Swedish Labour Market. Journal of Ethnic and Migration Studies, 34(3), 411-430. https://doi.org/10.1080/13691830701880251

Behtoui, A. (2013). Incorporation of children of immigrants: the case of descendants of immigrants from Turkey in Sweden. Ethnic and Racial Studies, 36(12), 2141-2159. https://doi.org/10.1080/01419870.2012.696667

Bergmark, Å., \& Bäckman, O. (2004). Stuck with Welfare? Long-term Social Assistance Recipiency in Sweden. European Sociological Review, 20(5), 425-443. https://doi.org/10.1093/esr/jch036

Bergmark, A., \& Palme, J. (2003). Welfare and the unemployment crisis: Sweden in the 1990s. International Journal of Social Welfare, 12(2), 108-122. https://doi.org/10.1111/1468-2397.00249

Bevelander, P. (1999). The employment integration of immigrants in Sweden. Journal of Ethnic and Migration Studies, 25(3), 445468. https://doi.org/10.1080/1369183X.1999.9976695 
Bevelander, P. (2005). The Employment Status of Immigrant Women: The Case of Sweden. International Migration Review, 39(1), 173202. https://doi.org/10.2307/27645480

Bevelander, P. (2011). The Employment Integration of Resettled Refugees, Asylum Claimants, and Family Reunion Migrants in Sweden. Refugee Survey Quarterly, 30(1), 22-43. https://doi.org/10.1093/rsq/hdq041

Bevelander, P., \& Pendakur, R. (2012). Citizenship, Co-ethnic Populations, and Employment Probabilities of Immigrants in Sweden. Journal of International Migration and Integration, 13, 203-222. https://doi.org/10.1007/s12134-011-0212-6

Bevelander, P., \& Pendakur, R. (2014). The labour market integration of refugee and family reunion immigrants: a comparison of outcomes in Canada and Sweden. Journal of Ethnic and Migration Studies, 40(5), 689-709. https://doi.org/10.1080/1369183x.2013.849569

Birgier, D. P., Lundh, C., Haberfeld, Y., \& Elldér, E. (2018). SelfSelection and Host Country Context in the Economic Assimilation of Political Refugees in the United States, Sweden, and Israel. International Migration Review, 52(2), 524-558. https://doi.org/10.1111/imre.12309

Blau, F. D., Kahn, L. M., \& Papps, K. L. (2011). Gender, Source Country Characteristics, and Labor Market Assimilation among Immigrants. Review of Economics and Statistics, 93(1), 43-58. https://doi.org/10.1162/REST_a_00064

Blau, P. M., \& Duncan, O. D. (1978). The American occupational structure. The Free Press.

Blossfeld, H.-P., Golsch, K., \& Rohwer, G. (2007). Event History Analysis Using Stata. Psychology Press.

Borevi, K. (2014). Multiculturalism and welfare state integration: Swedish model path dependency. Identities, 21(6), 708-723. https://doi.org/10.1080/1070289x.2013.868351

Borjas, G. J. (1985). Assimilation, Changes in Cohort Quality, and the Earnings of Immigrants. Journal of Labor Economics, 3(4), 463. https://doi.org/10.1086/298065

Borjas, G. J. (1986). The Self-Employment Experience of Immigrants. The Journal of Human Resources, 21(4), 485-506. https://doi.org/10.2307/145764 
Borjas, G. J. (1989). Economic Theory and International Migration. International Migration Review, 23(3), 457-485. https://doi.org/10.2307/2546424

Bowles, S., \& Gintis, H. (1975). The problem with human capital theory - marxian critique. American Economic Review, 65(2), 74-82.

Bratsberg, B., \& Terrell, D. (2002). School Quality and Returns to the Education of U.S. Immigrants. Economic Inquiry, 40(2), 177-198. https://doi.org/10.1093/ei/40.2.177

Brell, C., Dustmann, C., \& Preston, I. (2020). The Labor Market Integration of Refugee Migrants in High-Income Countries. Journal of Economic Perspectives, 34(1), 94-121. https://doi.org/10.1257/jep.34.1.94

Brubaker, R. (2001). The return of assimilation? Changing perspectives on immigration and its sequels in France, Germany, and the United States. Ethnic and Racial Studies, 24(4), 531-548. https://doi.org/10.1080/01419870120049770

Bursell, M. (2012). Ethnic Discrimination, Name Change and Labor Market Inequality : Mixed approaches to ethnic exclusion in Sweden (Stockholm Studies in Sociology, New Series 54) [Doctoral dissertation, Stockholm University]. DiVA.

Bursell, M. (2012b). Name change and destigmatization among Middle Eastern immigrants in Sweden. Ethnic and Racial Studies, 35(3), 471-487. https://doi.org/10.1080/01419870.2011.589522

Bursell, M. (2014). The Multiple Burdens of Foreign-Named MenEvidence from a Field Experiment on Gendered Ethnic Hiring Discrimination in Sweden. European Sociological Review, 30(3), 399-409. https://doi.org/10.1093/esr/jcu047

Bursell, M., Bygren, M., \& Gähler, M. (2021). Does employer discrimination contribute to the subordinate labor market inclusion of individuals of a foreign background? Social Science Research. https://doi.org/10.1016/j.ssresearch.2021.102582

Butschek, S., \& Walter, T. (2014). What active labour market programmes work for immigrants in Europe? A meta-analysis of the evaluation literature. IZA Journal of Migration, 3(1), 48. https://doi.org/10.1186/s40176-014-0023-6

Buzdugan, R., \& Halli, S. S. (2009). Labor Market Experiences of Canadian Immigrants with Focus on Foreign Education and Experience. International Migration Review, 43(2), 366-386. https://doi.org/10.1111/j.1747-7379.2009.00768.x 
Böhlmark, A. (2009). Integration of Childhood Immigrants in the Short and Long Run - Swedish Evidence. International Migration Review, 43(2), 387-409. https://doi.org/10.1111/j.17477379.2009.00769.x

Castles, S. (2010). Understanding Global Migration: A Social Transformation Perspective. Journal of Ethnic and Migration Studies, 36(10), 1565-1586. https://doi.org/10.1080/1369183x.2010.489381

Castles, S., De Haas, H., \& Miller, M. J. (2014). The Age of Migration. International Population Movements In the Modern World. (5th ed.). Palgrave Macmillan.

Cebolla-Boado, H., \& Miyar-Busto, M. (2019). Are They Deterred by Welfare? Digging into the Drivers of Highly Skilled Temporary and Long-term Migrants in Europe. International Migration, 58(2), 180-204. https://doi.org/10.1111/imig.12631

Chiswick, B. R. (1978). The Effect of Americanization on the Earnings of Foreign-born Men. Journal of Political Economy, 86(5), 897921. https://doi.org/10.1086/260717

Chiswick, B. R. (1999). Are Immigrants Favorably Self-Selected? American Economic Review, 89(2), 181-185. https://doi.org/10.2307/117103

Chiswick, B. R., Lee, Y. L., \& Miller, P. W. (2005). Immigrant earnings: A longitudinal analysis. Review of Income and Wealth, 51(4), 485-503. https://doi.org/10.1111/j.1475-4991.2005.00165.x

Chiswick, B. R., \& Miller, P. W. (2009). The international transferability of immigrants' human capital. Economics of Education Review, 28(2), 162-169. https://doi.org/10.1016/j.econedurev.2008.07.002

Chiswick, B. R., \& Miller, P. W. (2012). Negative and Positive Assimilation, Skill Transferability, and Linguistic Distance. Journal of Human Capital, 6(1), 35-55. https://doi.org/10.1086/664794

Clark, K., \& Drinkwater, S. (2000). Pushed out or pulled in? Selfemployment among ethnic minorities in England and Wales. Labour Economics, 7(5), 603-628. https://doi.org/10.1016/S0927-5371(00)00015-4

Coleman, J. S. (1988). Social Capital in the Creation of Human Capital. American Journal of Sociology, 94, S95-S120. 
Damelang, A., Ebensperger, S., \& Stumpf, F. (2020). Foreign Credential Recognition and Immigrants' Chances of Being Hired for Skilled Jobs-Evidence from a Survey Experiment Among Employers. Social Forces. https://doi.org/10.1093/sf/soz154

Damelang, A., Ebensperger, S., \& Stumpf, F. (2021). Immigrants' Labour Market Disadvantages Across Western Europe: the Role of Composition and Context. Journal of International Migration and Integration. https://doi.org/10.1007/s12134-021-00823-3

Damelang, A., \& Kosyakova, Y. (2021). To work or to study? Postmigration educational investments of adult refugees in Germany - Evidence from a choice experiment. Research in Social Stratification and Mobility, 73. https://doi.org/10.1016/j.rssm.2021.100610

Davis, K., \& Moore, W. E. (1945). Some Principles of Stratification. American Sociological Review, 10(2), 242-249. https://doi.org/10.2307/2085643

De Genova, N. P. (2002). Migrant "Illegality" and Deportability in Everyday Life. Annual Review of Anthropology, 31(1), 419-447. https://doi.org/10.1146/annurev.anthro.31.040402.085432

de Haas, H. (2010). The Internal Dynamics of Migration Processes: A Theoretical Inquiry. Journal of Ethnic \& Migration Studies, $36(10)$, 1587-1617. https://doi.org/10.1080/1369183X.2010.489361

de Haas, H., Natter, K., \& Vezzoli, S. (2018). Growing Restrictiveness or Changing Selection? The Nature and Evolution of Migration Policies1. International Migration Review, 52(2), 324-367. https://doi.org/10.1111/imre.12288

de los Reyes, P. (1998). I skärningspunkten mellan genus och etnicitet. Ett ekonomiskt historiskt perspektiv på invandrarkvinnor i svenskt arbetsliv. Arbetsmarknad \& Arbetsliv, 4(1), 13-31.

de los Reyes, P. (2000). Diversity at Work: Paradoxes, Possibilities and Problems in the Swedish Discourse on Diversity. Economic and Industrial Democracy, 21(2), 253-266. https://doi.org/10.1177/0143831x00212007

Delaporte, I., \& Piracha, M. (2018). Integration of humanitarian migrants into the host country labour market: evidence from Australia. Journal of Ethnic and Migration Studies, 44(15), 2480-2505. https://doi.org/10.1080/1369183x.2018.1429901 
Duvander, A.-Z. E. (2001). Do Country-Specific Skills Lead to Improved Labor Market Positions? Work and Occupations, 28(2), 210-233. https://doi.org/10.1177/0730888401028002005

Edling, C., \& Rydgren, J. (2016). Social Mechanisms in Empirical Sociology: Introduction to Special Issue. American Behavioral Scientist, 60(10),

1135-1145. https://doi.org/10.1177/0002764216643128

Ekberg, J., \& Hammarstedt, M. (2002). 20 år med allt sämrearbetsmarknadsintegrering för invandrare. Ekonomisk Debatt, 30(4), 343-353.

Elster, J. (1989). Nuts and Bolts for the Social Sciences. Cambridge University Press.

England, P., Allison, P., \& Wu, Y. (2007). Does bad pay cause occupations to feminize, Does feminization reduce pay, and How can we tell with longitudinal data? Social Science Research, 36(3),

1237-1256. https://doi.org/10.1016/j.ssresearch.2006.08.003

Eriksson, R., \& Goldthorpe, J. H. (1992). The Constant Flux: A Study of Class Mobility in Industrial Societies. Clarendon Press.

Evans, D., S., \& Jovanovic, B. (1989). An Estimated Model of Entrepreneurial Choice under Liquidity Constraints. Journal of Political Economy, 97(4), 808. https://doi.org/10.1086/261629

Evans, D., S., \& Leighton, L., S. (1989). Some Empirical Aspects of Entrepreneurship. The American Economic Review, 79(3), 519.

Feliciano, C. (2020). Immigrant Selectivity Effects on Health, Labor Market, and Educational Outcomes. Annual Review of Sociology, 46(1), 315-334. https://doi.org/10.1146/annurev-soc-121919054639

Fellini, I., \& Guetto, R. (2019). A "U-Shaped" Pattern of Immigrants' Occupational Careers? A Comparative Analysis of Italy, Spain, and France. International Migration Review, 53(1), 26-58. https://doi.org/10.1177/0197918318767931

Fossati, F., Liechti, F., \& Auer, D. (2019). Can signaling assimilation mitigate hiring discrimination? Evidence from a survey experiment. Research in Social Stratification and Mobility. https://doi.org/10.1016/j.rssm.2019.100462

Friberg, J. H., \& Midtbøen, A. H. (2018). Ethnicity as skill: immigrant employment hierarchies in Norwegian low-wage labour markets. 
Journal of Ethnic and Migration Studies, 44(9), 1463-1478. https://doi.org/10.1080/1369183x.2017.1388160

Friedberg, R. M. (2000). You Can't Take It with You? Immigrant Assimilation and the Portability of Human Capital. Journal of Labor Economics, 18(2), 221-251. https://doi.org/10.1086/209957

Fuller, S. (2018). Do Pathways Matter? Linking Early Immigrant Employment Sequences and Later Economic Outcomes: Evidence from Canada. International Migration Review, 49(2), 355-405. https://doi.org/10.1111/imre.12094

Goldthorpe, J. H. (2000). On sociology: numbers, narratives, and the integration of research and theory. Oxford University Press.

Goldthorpe, J. H. (2015). Sociology as a Population Science. Cambridge University Press. https://doi.org/DOI: 10.1017/CBO9781316412565

Gordon, M. (1964). Assimilation in American Life: The Role of Race, Religion and National Origins. Oxford University Press.

Granovetter, M. (1974). Getting a job: A study of contacts and careers. Chicago of University Press.

Grogger, J., \& Hanson, G. H. (2011). Income maximization and the selection and sorting of international migrants. Journal of Development Economics, 95(1), 42-57. https://doi.org/10.1016/j.jdeveco.2010.06.003

Gross, N. (2009). A Pragmatist Theory of Social Mechanisms. American Sociological Review, 74(3), 358-379. https://doi.org/10.1177/000312240907400302

Grönberg, P.-O., Lundh Nilsson, F., \& Sandström, G. (2015). Desirable skills? Non-Nordic citizens applying for work permits in Sweden, 1947-1950. Labor History, 56(4), 481-498. https://doi.org/10.1080/0023656x.2016.1086556

Gustafsson, B., \& Zheng, J. (2006). Earnings of Immigrants in Sweden, 1978 to 1999. International Migration, 44(2), 79-117. https://doi.org/10.1111/j.1468-2435.2006.00365.x

Haberfeld, Y., Birgier, D. P., Lundh, C., \& Elldér, E. (2020). Migration across developed countries: German immigrants in Sweden and the US. International Migration. https://doi.org/10.1111/imig.12706

Haberfeld, Y., \& Lundh, C. (2014). Self-Selection and Economic Assimilation of Immigrants: The Case of Iranian Immigrants 
Arriving to Three Countries During 1979-1985. International Migration Review, 48(2), 354-386. https://doi.org/10.1111/imre.12080

Hammarstedt, M. (2003). Income from Work among Immigrants in Sweden. Review of Income and Wealth, 49(2), 185-203. https://doi.org/10.1111/1475-4991.00082

Hammarstedt, M., \& Shukur, G. (2006). Immigrants' Relative Earnings in Sweden - A Cohort Analysis. Labour, 20(2), 285-323. https://doi.org/10.1111/j.1467-9914.2006.00339.x

Hansen, P. (2021). A Modern Migration Theory. An Alternative Economic Approachto Failed EU Policy. Agenda Publishing Limited.

Hartog, J. (2000). Over-education and earnings: where are we, where should we go? Economics of Education Review, 19(2), 131-147. https://doi.org/http://dx.doi.org/10.1016/S0272-7757(99)000503

Hedström, P., \& Ylikoski, P. (2010). Causal Mechanisms in the Social Sciences. Annual Review of Sociology, 36(1), 49-67. https://doi.org/10.1146/annurev.soc.012809.102632

Helbling, M., Simon, S., \& Schmid, S. D. (2020). Restricting immigration to foster migrant integration? A comparative study across 22 European countries. Journal of Ethnic and Migration Studies, 46(13), 2603-2624. https://doi.org/10.1080/1369183x.2020.1727316

Helgertz, J. (2010). Immigrant Careers - Why Country of Origin Matters (Lund Studies in Economic History 53) [Doctoral dissertation, Lund University]. Lund University Publications.

Helgertz, J. (2011). Thou shalt not pass? Examining the existence of an immigrant glass ceiling in Sweden, 1970-1990. Demographic Research, 24(1), 1-44. https://doi.org/10.4054/DemRes.2011.24.1

Helgertz, J. (2013). Pre- to Post-Migration Occupational Mobility of First Generation Immigrants to Sweden from 1970-1990: Examining the Influence of Linguistic Distance. Population Research and Policy Review, 32(3), 437-467. https://doi.org/10.1007/s11113013-9274-9

Helgertz, J., Bevelander, P., \& Tegunimataka, A. (2014). Naturalization and Earnings: A Denmark-Sweden Comparison. European 
Journal of Population, 30(3), 337-359. https://doi.org/10.1007/s10680-014-9315-z

Hjerm, M. (2004). Immigrant Entrepreneurship in the Swedish Welfare State.

739-756. https://doi.org/10.1177/0038038504045862

Hollifield, J. F. (2004). The Emerging Migration State. International Migration Review, 38(3), 885-912. https://doi.org/10.1111/j.1747-7379.2004.tb00223.x

Hout, M., \& Rosen, H. (2000). Self-Employment, Family Background, and Race. The Journal of Human Resources, 35(4), 670-692. https://doi.org/10.2307/146367

Hudson, K. (2007). The new labor market segmentation: Labor market dualism in the new economy. Social Science Research, 36(1), 286-312. https://doi.org/10.1016/j.ssresearch.2005.11.005

Härkönen, J., \& Bihagen, E. (2011). Occupational Attainment and Career Progression in Sweden. European Societies, 13(3), 451-479. https://doi.org/10.1080/14616696.2011.568261

International Organization for Migration. (2019). Glossary on Migration. IML Series No. 34. International Organization for Migration.

Irastorza, N., \& Bevelander, P. (2021). Skilled Migrants in the Swedish Labour Market: An Analysis of Employment, Income and Occupational Status. Sustainability, 13(6), 3428. https://doi.org/10.3390/su13063428

Irvine, J. T. (1989). When Talk Isn't Cheap: Language and Political Economy. American Ethnologist, 16(2), 248-267. https://doi.org/10.1525/ae.1989.16.2.02a00040

Jacobs, D., Swyngedouw, M., Hanquinet, L., Vandezande, V., Andersson, R., Horta, A. P. B., Berger, M., Diani, M., Ferrer, A. G., Giugni, M., Morariu, M., Pilati, K., \& Statham, P. (2009). The challenge of measuring immigrant origin and immigration-related ethnicity in Europe. Journal of International Migration and Integration, 10(1), 67-88. https://doi.org/10.1007/s12134-0090091-2

Juárez, S. P., Honkaniemi, H., Dunlavy, A. C., Aldridge, R. W., Barreto, M. L., Katikireddi, S. V., \& Rostila, M. (2019). Effects of nonhealth-targeted policies on migrant health: a systematic review and meta-analysis. The Lancet Global Health, 7(4), e420-e435. https://doi.org/https://doi.org/10.1016/S2214-109X(18)30560-6 
Jutvik, K. (2020). Governing Migration : On the Emergence and Effects of Policies Related to the Settlement and Inclusion of Refugees (Digital Comprehensive Summaries of Uppsala Dissertations from the Faculty of Social Sciences 177) [Doctoral dissertation, Uppsala University]. DiVA.

Kalleberg, A. L., \& Sorensen, A. B. (1979). Sociology of labour-markets. Annual Review of Sociology, 5, 351-379. https://doi.org/10.1146/annurev.so.05.080179.002031

Kalter, F., \& Kogan, I. (2014). Migrant Networks and Labor Market Integration of Immigrants from the Former Soviet Union in Germany. Social Forces, 92(4), 1435-1456. https://doi.org/10.1093/sf/sot155

Kanas, A., Chiswick, B. R., van der Lippe, T., \& van Tubergen, F. (2012). Social Contacts and the Economic Performance of Immigrants: A Panel Study of Immigrants in Germany. International Migration Review, 46(3), 680-709. https://doi.org/10.1111/j.17477379.2012.00901.x

Kanas, A., \& Müller, K. (2021). Immigrant Women's Economic Outcomes in Europe: The Importance of Religion and Traditional Gender Roles. International Migration Review, 019791832110088. https://doi.org/10.1177/01979183211008867

Kanas, A., \& Steinmetz, S. (2020). Economic Outcomes of Immigrants with Different Migration Motives: The Role of Labour Market Policies. European Sociological Review. https://doi.org/10.1093/esr/jcaa058

Kanas, A., \& van Tubergen, F. (2009). The Impact of Origin and Host Country Schooling on the Economic Performance of Immigrants. Social Forces, 88(2), 893-915. https://doi.org/10.1353/sof.0.0269

Karlin, C. A., England, P., \& Richardson, M. (2002). Why do "Women's jobs" have low pay for their educational level?. Gender Issues, 20(4), 3-22. https://doi.org/10.1007/s12147-002-0020-6

Karlsson, J., \& Tibajev, A. (2014). Utlandsföddas levnadsvillkor. Bakgrund, migration och arbetsliv. In M. Evertsson \& C. Magnusson (Eds.), Ojämlikhetens dimensioner: uppväxtvillkor, arbete och hälsa i Sverige (pp. 263-287). Liber.

Kesler, C. (2006). Social Policy and Immigrant Joblessness in Britain, Germany and Sweden. Social Forces, 85(2), 743. https://doi.org/10.1353/sof.2007.0013 
Kesler, C. (2010). Immigrant Wage Disadvantage in Sweden and the United Kingdom: Wage Structure and Barriers to Opportunity1. International Migration Review, 44(3), 560-592. https://doi.org/10.1111/j.1747-7379.2010.00818.x

Kesler, C. (2015). Welfare states and immigrant poverty: Germany, Sweden, and the United Kingdom in comparative perspective. Acta Sociologica, 58(1), 39-61. https://doi.org/10.1177/0001699314560238

Kluve, J. (2010). The effectiveness of European active labor market programs. Labour Economics, 17(6), 904-918. https://doi.org/10.1016/j.labeco.2010.02.004

Kogan, I. (2003). Ex-Yugoslavs in the Austrian and Swedish labour markets: The significance of the period of migration and the effect of citizenship acquisition. Journal of Ethnic and Migration Studies, 29(4), 595-622. https://doi.org/10.1080/1369183032000123413

Kogan, I. (2004). Last Hired, First Fired? The Unemployment Dynamics of Male Immigrants in Germany. European Sociological Review, 20(5), 445-461. https://doi.org/10.1093/esr/jch037

Kogan, I. (2006). Labor Markets and Economic Incorporation among Recent Immigrants in Europe. Social Forces, 85(2), 697. https://doi.org/10.1353/sof.2007.0014

Kogan, I., Shen, J., \& Siegert, M. (2018). What Makes a Satisfied Immigrant? Host-Country Characteristics and Immigrants' Life Satisfaction in Eighteen European Countries. Journal of Happiness Studies, 19(6), 1783-1809. https://doi.org/10.1007/s10902-017-9896-4

Kogan, I., \& Weißmann, M. (2013). Immigrants' initial steps in Germany and their later economic success. Advances in Life Course Research, 18(3), 185-198. https://doi.org/10.1016/j.alcr.2013.04.002

Korpi, T., \& Tåhlin, M. (2009). Educational mismatch, wages, and wage growth: Overeducation in Sweden, 1974-2000. Labour Economics, 16(2), 183-193. https://doi.org/10.1016/j.labeco.2008.08.004

Korpi, T., \& Tåhlin, M. (2021). On-the-job training: a skill match approach to the determinants of lifelong learning. Industrial Relations Journal, 52(1), 64-81. https://doi.org/10.1111/irj.12317 
Kracke, N., \& Klug, C. (2021). Social Capital and Its Effect on Labour Market (Mis)match: Migrants' Overqualification in Germany. Journal of International Migration and Integration. https://doi.org/10.1007/s12134-021-00817-1

Lamont, M., Beljean, S., \& Clair, M. (2014). What is missing? Cultural processes and causal pathways to inequality. Socio-Economic Review, 12(3), 573-608. https://doi.org/10.1093/ser/mwu011

Lancee, B. (2010). The Economic Returns of Immigrants' Bonding and Bridging Social Capital: The Case of the Netherlands. International Migration Review, 44(1), 202-226. https://doi.org/10.1111/j.1747-7379.2009.00803.x

Lancee, B. (2016). Job search methods and immigrant earnings: A longitudinal analysis of the role of bridging social capital. Ethnicities, $16(3)$

349-367. https://doi.org/10.1177/1468796815581426

Lancee, B., \& Bol, T. (2017). The transferability of skills and degrees: Why the place of education affects immigrant earnings. Social Forces, 96(2), 691-716. https://doi.org/10.1093/sf/sox058

Larsson, J. K. (2015). Integrationen och arbetets marknad: Hur jämställdhet, arbete och annat "svenskt" görs av arbetsförmedlare och privata aktörer (Linköping Studies in Arts and Science 661) [Doctoral dissertation, Linköping University]. https://doi.org/10.3384/diss.diva-122907

le Grand, C., \& Szulkin, R. (2002). Permanent Disadvantage or Gradual Integration: Explaining the Immigrant-Native Earnings Gap in Sweden. Labour, 16(1), 37-64. https://doi.org/10.1111/14679914.00186

le Grand, C., \& Tåhlin, M. (2013). Class, Occupation, Wages, and Skills: The Iron Law of Labor Market Inequality. Comparative Social Research, 30, 3-46. https://doi.org/10.1108/s01956310(2013)0000030006

Light, I. (1984). Immigrant and ethic enterprise in North America. Ethnic and Racial Studies, 7(2), 195-216. https://doi.org/10.1080/01419870.1984.9993441

Lin, N. (1999). Social Networks and Status Attainment. Annual Review of Sociology, 25, 467. https://doi.org/10.1146/annurev.soc.25.1.467

Lodigiani, R., \& Sarli, A. (2017). Migrants' competence recognition systems: controversial links between social inclusion aims and 
unexpected discrimination effects. European Journal for Research on the Education and Learning of Adults, 8(1), 127-144. https://doi.org/10.3384/rela.2000-7426.rela0201

Lubotsky, D. (2007). Chutes or Ladders? A Longitudinal Analysis of Immigrant Earnings. Journal of Political Economy, 115(5), 820867. https://doi.org/10.1086/522871

Luik, M.-A., Emilsson, H., \& Bevelander, P. (2016). Explaining the Male Native-Immigrant Employment Gap in Sweden: The Role of Human Capital and Migrant Categories. IZA Institute of Labor Economics.

Lundborg, P. (2013). Refugees' Employment Integration in Sweden: Cultural Distance and Labor Market Performance. Review of International Economics, 21(2), 219-232. https://doi.org/10.1111/roie.12032

Lundh, C., \& Ohlsson, R. (1999). Från arbetskraftsimport till flyktinginvandring (2 ed.). Studieförbundet Näringsliv och Samhälle.

Luthra, R., Platt, L., \& Salamońska, J. (2018). Types of Migration: The Motivations, Composition, and Early Integration Patterns of "New Migrants" in Europe. International Migration Review, 52(2), 368-403. https://doi.org/10.1177/0197918318781586

Lutz, H. (2010). Gender in the Migratory Process. Journal of Ethnic and Migration Studies, 36(10), 1647-1663. https://doi.org/10.1080/1369183x.2010.489373

Massey, D. S., Arango, J., Hugo, G., Kouaouci, A., Pellegrino, A., \& Taylor, J. E. (1993). Theories of International Migration: A Review and Appraisal. Population and Development Review, 19(3), 431-466. https://doi.org/10.2307/2938462

Mattsson, K. (2001). (O)likhetens geografier : Marknaden, forskningen och de Andra (Geografiska regionstudier 45) [Doctoral dissertation, Uppsala University]. DiVA.

McDowell, L. (2009). Old and New European Economic Migrants: Whiteness and Managed Migration Policies. Journal of Ethnic and Migration Studies, 35(1), 19-36. https://doi.org/10.1080/13691830802488988

Midtbøen, A. H. (2015). Ethnic Penalties In Western Labour Markets. Nordic Journal of Migration Research, 5(4), 185. https://doi.org/10.1515/njmr-2015-0022 
Mincer, J. (1974). Schooling, Experience and Earnings. National Bureau of Economic Research.

Morgan, S. L., \& Winship, C. (2014). Counterfactuals and Causal Inference: Methods and Principles for Social Research (2nd ed.). Cambridge University Press.

Moss, P., \& Tilly, C. (1996). "Soft" Skills and Race. Work and Occupations, 23(3), 252-276. https://doi.org/10.1177/0730888496023003002

Neuman, E. (2018). Source country culture and labor market assimilation of immigrant women in Sweden: evidence from longitudinal data. Review of Economics of the Household, 16(3), 585-627. https://doi.org/10.1007/s11150-018-9420-6

Nilsson, A. (2004). Efterkrigstidens invandring och utvandring. Statistics Sweden.

Nordin, M., \& Rooth, D.-O. (2009). The Ethnic Employment and Income Gap in Sweden: Is Skill or Labor Market Discrimination the Explanation? Scandinavian Journal of Economics, 111(3), 487510. https://doi.org/10.1111/j.1467-9442.2009.01573.x

Nygård, O. (2020). Educational Aspirations and Attainments : How resources relate to outcomes for children of immigrants in disadvantaged Swedish schools (Linköping Studies in Arts and Sciences 796) [Doctoral dissertation, Linköping University]. https://doi.org/10.3384/diss.diva-169376

Nygård, O. (2021). Pre-Migration Status, Social Capital, and the Educational Aspirations of Children of Immigrants in Disadvantaged Swedish Schools. Scandinavian Journal of Educational Research, $1-14$. https://doi.org/10.1080/00313831.2021.1897878

Obucina, O. (2013). Paths into and out of poverty among immigrants in Sweden. Acta Sociologica, $57(1)$ $5-23$. https://doi.org/10.1177/0001699313495055

OECD. (2021). Employment, unemployment, and participation rates by place of birth and sex. Retrieved 1 November from https://stats.oecd.org/Index.aspx?DataSetCode=MIG

Oesch, D., \& Piccitto, G. (2019). The Polarization Myth: Occupational Upgrading in Germany, Spain, Sweden, and the UK, 1992-2015. Work and Occupations, 46(4), 441-469. https://doi.org/10.1177/0730888419860880 
Oláh, L. S., \& Bernhardt, E. (2008). Sweden: Combining childbearing and gender equality. Demographic Research, 19, 1105-1144. https://doi.org/10.4054/demres.2008.19.28

Oláh, L. S., Kotowska, I. E., \& Richter, R. (2018). The New Roles of Men and Women and Implications for Families and Societies. In G. Doblhammer \& J. Gumà (Eds.), A Demographic Perspective on Gender, Family and Health in Europe (pp. 41-64). https://doi.org/10.1007/978-3-319-72356-3_4

Panichella, N. (2018). Economic crisis and occupational integration of recent immigrants in Western Europe. International Sociology, 33(1), 64-85. https://doi.org/10.1177/0268580917742002

Pendakur, K., \& Pendakur, R. (2002). Language as Both Human Capital and Ethnicity. International Migration Review, 36(1), 147-177. https://doi.org/10.2307/4149533

Penninx, R. (2019). Problems of and solutions for the study of immigrant integration. Comparative Migration Studies, 7(1), 13. https://doi.org/10.1186/s40878-019-0122-x

Pichler, F. (2011). Success on European Labor Markets: A Cross-national Comparison of Attainment between Immigrant and Majority Populations. International Migration Review, 45(4), 938-978. https://doi.org/10.1111/j.1747-7379.2011.00873.x

Piore, M. J. (1979). Birds of Passage: Migrant Labor and Industrial Societies. Cambridge University Press. https://doi.org/DOI: 10.1017/CBO9780511572210

Platt, L., Polavieja, J., \& Radl, J. (2021). Which Integration Policies Work? The Heterogeneous Impact of National Institutions on Immigrants' Labor Market Attainment in Europe. International Migration Review, 019791832110326. https://doi.org/10.1177/01979183211032677

Portes, A., \& Vickstrom, E. (2011). Diversity, Social Capital, and Cohesion. Annual Review of Sociology, 37(1), 461-479. https://doi.org/10.1146/annurev-soc-081309-150022

Portes, A., \& Zhou, M. I. N. (1993). The New Second Generation: Segmented Assimilation and its Variants. The ANNALS of the American Academy of Political and Social Science, 530(1), 7496. https://doi.org/10.1177/0002716293530001006

Qi, H., Irastorza, N., Emilsson, H., \& Bevelander, P. (2021). Integration policy and refugees' economic performance: Evidence from 
Sweden's 2010 reform of the introduction programme. International Migration. https://doi.org/10.1111/imig.12813

Quillian, L., Heath, A., Pager, D., Midtbøen, A., Fleischmann, F., \& Hexel, O. (2019). Do Some Countries Discriminate More than Others? Evidence from 97 Field Experiments of Racial Discrimination in Hiring. Sociological Science, 6, 467-496. https://doi.org/10.15195/v6.a18

Razin, A., \& Wahba, J. (2015). Welfare Magnet Hypothesis, Fiscal Burden, and Immigration Skill Selectivity. Scandinavian Journal of Economics, 117(2), 369-402. https://doi.org/10.1111/sjoe.12092

Reitz, J. G. (2001). Immigrant Success in the Knowledge Economy: Institutional Change and the Immigrant Experience in Canada, 1970-1995. Journal of Social Issues, 57(3), 579-613. https://doi.org/10.1111/0022-4537.00230

Rooth, D.-O., \& Saarela, J. (2007). Selection in migration and return migration: Evidence from micro data. Economics Letters, 94(1), 90-95. https://doi.org/10.1016/j.econlet.2006.08.006

Rosholm, M., Scott, K., \& Husted, L. (2006). The Times They Are AChangin': Declining Immigrant Employment Opportunities in Scandinavia. International Migration Review, 40(2), 318-347. https://doi.org/10.1111/j.1747-7379.2006.00019.x

Rydgren, J. (2004). Mechanisms of exclusion: ethnic discrimination in the Swedish labour market. Journal of Ethnic and Migration Studies, 30(4), 697-716. https://doi.org/10.1080/13691830410001699522

Schaafsma, J., \& Sweetman, A. (2001). Immigrant earnings: Age at immigration matters. Canadian Journal of Economics, 34(4), 1066-1099. https://doi.org/10.1111/0008-4085.00113

Schierup, C.-U., Hansen, P., \& Castles, S. (2006). Migration, Citizenship, and the European Welfare State: A European Dilemma. Oxford Scholarship Online. https://doi.org/10.1093/0198280521.001.000 Schierup, C. U., \& Ålund, A. (2011). The end of Swedish exceptionalism? Citizenship, neoliberalism and the politics of exclusion. Race and Class, 53(1), 45-64. https://doi.org/10.1177/0306396811406780

Schmidt, R., Kristen, C., \& Mühlau, P. (2021). Educational Selectivity and Immigrants' Labour Market Performance in Europe. 
European

Review. https://doi.org/10.1093/esr/jcab042

Schrover, M., van der Leun, J., \& Quispel, C. (2007). Niches, Labour Market Segregation, Ethnicity and Gender. Journal of Ethnic and Migration Studies, 33(4), 529-540. https://doi.org/10.1080/13691830701265404

Seibel, V., \& van Tubergen, F. (2013). Job-Search Methods Among NonWestern Immigrants in the Netherlands. Journal of Immigrant \& Refugee Studies, 11(3), 241-258. https://doi.org/10.1080/15562948.2013.801727

Siebers, H. (2018). When Nationalism Meets Soft Skills. In C. Rijken (Ed.), Towards a Decent Labour Market for Low-Waged Migrant Workers (pp. 247-266). Amsterdam University Press. https://doi.org/10.1515/9789048539253-012

Siebers, H., \& van Gastel, J. (2015). Why migrants earn less: in search of the factors producing the ethno-migrant pay gap in a Dutch public organization. Work, employment and society, 29(3), 371-391. https://doi.org/10.1177/0950017014568138

Simon, P., \& Piché, V. (2012). Accounting for ethnic and racial diversity: the challenge of enumeration. Ethnic and Racial Studies, 35(8), 1357-1365. https://doi.org/10.1080/01419870.2011.634508

Slavnic, Z. (2010). Political Economy of Informalization. European Societies, $12(1)$, $3-23$. https://doi.org/10.1080/14616690903042724

Solano, G., \& Huddleston, T. (2020). Migrant Integration Policy Index 2020 (Vol. 2020). CIDOB and MPG. www.mipex.eu

Sorensen, A. B. (1977). The Structure of Inequality and the Process of Attainment. American Sociological Review, 42(6), 965. https://doi.org/10.2307/2094580

Spence, M. (1973). Job Market Signaling. The Quarterly Journal of Economics, 87(3), 355-374. https://doi.org/10.2307/1882010

Statistics Sweden. (2021). Invandringar (medborgare utom Norden) efter grund för bosättning, ålder och år. Retrieved 1 November from https://www.statistikdatabasen.scb.se/sq/117640

Stiglitz, J. E. (1975). The Theory of "Screening," Education, and the Distribution of Income. The American Economic Review, 65(3), 283-300.

Svanberg, J. (2011). Labour Migration and the Swedish Labour Market Model: a case study of recruitment of Yugoslav workers to 
Andrey Tibajev

Svenska Fläktfabriken in Växjö, 1969-1970. Scandinavian Journal of History, 36(1), 91-113. https://doi.org/10.1080/03468755.2010.540702

Swedish Institute for Social Research. (2017). The Swedish Level-ofLiving Survey (LNU). Retrieved 1 June 2021 from https://www.sofi.su.se/english/2.17851/research/three-researchunits/lnu-level-of-living/the-swedish-level-of-living-survey-lnu1.65112

Sweetland, S. R. (1996). Human Capital Theory: Foundations of a Field of Inquiry. Review of Educational Research, 66(3), 341-359. https://doi.org/10.3102/00346543066003341

Tan, E. (2014). Human Capital Theory: A Holistic Criticism. Review of Educational Research, 84(3), 411-445. https://doi.org/10.3102/0034654314532696

Tani, M. (2019). Migration Policy and Immigrants' Labor Market Performance. International Migration Review, 0197918318815608. https://doi.org/10.1177/0197918318815608 Thijssen, L., Van Tubergen, F., Coenders, M., Hellpap, R., \& Jak, S. (2021). Discrimination of Black and Muslim Minority Groups in Western Societies: Evidence From a Meta-Analysis of Field Experiments. International Migration Review, 019791832110450. https://doi.org/10.1177/01979183211045044 Tilly, C. (1998). Durable Inequality. University of California Press.

Tomaskovic-Devey, D., Hällsten, M., \& Avent-Holt, D. (2015). Where Do Immigrants Fare Worse? Modeling Workplace Wage Gap Variation with Longitudinal Employer-Employee Data. American Journal of Sociology, 120(4), 1095-1143. https://doi.org/10.1086/679191

Tomaskovic-Devey, D., Thomas, M., \& Johnson, K. (2005). Race and the Accumulation of Human Capital across the Career: A Theoretical Model and Fixed-Effects Application. American Journal of Sociology, 111(1), 58-89. https://doi.org/10.1086/431779

Towns, A. (2002). Paradoxes of (In)Equality: Something is Rotten in the Gender Equal State of Sweden. Cooperation and Conflict, 37(2), 157-179. https://doi.org/10.1177/0010836702037002975

Tåhlin, M. (2007). Class Clues. European Sociological Review, 23(5), 557-572. https://doi.org/10.1093/esr/jcm019 
Ulfsdotter Eriksson, Y., \& Backman, C. (2014). Föreställningar om klass och kön i Arbetsförmedlingens yrkesbeskrivningar? Sociologisk Forskning, 51(2), 109-136.

Ulfsdotter Eriksson, Y., Larsson, B., \& Adolfsson, P. (2020). Employees of Greatness: Signifying Values in Performance Appraisal Criteria. Nordic Journal of Working Life Studies. https://doi.org/10.18291/njwls.122589

Urciuoli, B. (2008). Skills and selves in the new workplace. American Ethnologist, 35(2), 211-228. https://doi.org/10.1111/j.15481425.2008.00031.x

Valenta, M., \& Bunar, N. (2010). State Assisted Integration: Refugee Integration Policies in Scandinavian Welfare States: the Swedish and Norwegian Experience. Journal of Refugee Studies, 23(4), 463-483. https://doi.org/10.1093/jrs/feq028

Van Der Sluis, J., Van Praag, M., \& Vijverberg, W. (2008). Education and Entrepreneurship Selection and Performance: a Review of the Empirical Literature. Journal of Economic Surveys, 22(5), 795841. https://doi.org/10.1111/j.1467-6419.2008.00550.x

van Tubergen, F. (2005). Self-Employment of Immigrants: A CrossNational Study of 17 Western Societies. Social Forces, 84(2), 709-732. https://doi.org/10.1353/sof.2006.0039

van Tubergen, F., Maas, I., \& Flap, H. (2004). The Economic Incorporation of Immigrants in 18 Western Societies: Origin, Destination, and Community Effects. American Sociological Review, 69(5), 704-727. https://doi.org/10.2307/3593035

van Tubergen, F., \& Matthijs Kalmijn. (2005). Destination-Language Proficiency in Cross-National Perspective: A Study of Immigrant Groups in Nine Western Countries. American Journal of Sociology, 110(5), 1412-1457. https://doi.org/10.1086/428931

Wauters, B., \& Lambrecht, J. (2008). Barriers to Refugee Entrepreneurship in Belgium: Towards an Explanatory Model. Journal of Ethnic and Migration Studies, 34(6), 895-915. https://doi.org/10.1080/13691830802211190

Webster, N. A., \& Haandrikman, K. (2020). Exploring the Role of Privilege in Migrant Women's Self-Employment. Entrepreneurship Theory and Practice, 1-35. https://doi.org/10.1177/1042258720969139 
Wiesbrock, A. (2011). The Integration of Immigrants in Sweden: a Model for the European Union? International Migration, 49(4), 48-66. https://doi.org/10.1111/j.1468-2435.2010.00662.x

Wimmer, A., \& Glick Schiller, N. (2003). Methodological nationalism, the social sciences, and the study of migration: An essay in historical epistemology. International Migration Review, 37(3), 576-610. https://doi.org/10.1111/j.1747-7379.2003.tb00151.x

Wright, E. O. (2009). Understanding class: Towards an integrated analytical approach. New Left Review, (60), 101-116.

Zeng, Z., \& Xie, Y. (2004). Asian-Americans' Earnings Disadvantage Reexamined: The Role of Place of Education. American Journal of Sociology, 109(5), 1075-1108. https://doi.org/10.1086/381914

Zerubavel, E. (1996). Lumping and splitting: Notes on social classification. Sociological Forum, 11(3), 421-433. https://doi.org/10.1007/BF02408386

Zhang, T., \& Banerjee, R. (2021). Bridges or Barriers? The Relationship between Immigrants' Early Labor Market Adversities and Longterm Earnings. International Migration Review, 019791832110002. https://doi.org/10.1177/01979183211000286

Zschirnt, E., \& Ruedin, D. (2016). Ethnic discrimination in hiring decisions: a meta-analysis of correspondence tests 1990-2015. Journal of Ethnic and Migration Studies, 42(7), 1115-1134. https://doi.org/10.1080/1369183X.2015.1133279

Zwysen, W. (2019). Different Patterns of Labor Market Integration by Migration Motivation in Europe: The Role of Host Country Human Capital. International Migration Review, 53(1), 59-89. https://doi.org/10.1177/0197918318767929

Åslund, O., \& Rooth, D.-O. (2007). Do When and Where Matter? Initial Labour Market Conditions and Immigrant Earnings. Economic Journal, 117(518), 422-448. https://doi.org/10.1111/j.14680297.2007.02024. 


\section{Papers}

The papers associated with this thesis have been removed for copyright reasons. For more details about these see:

https://doi.org/10.3384/9789179291181 


\section{FACULTY OF ARTS AND SCIENCES}

Linköping Studies in Arts and Sciences No. 824

Department of Culture and Society (IKOS)

Division of Migration, Ethnicity and Society (REMESO)

Linköping University

SE-58183 Linköping, Sweden

www.liu.se

This dissertation focuses on the productive knowledge and skills, i.e. human capital, that immigrants bring from before immigration, as well as new human capital acquired in the destination country. The four studies included use registry and survey data to consider different aspects of labour market integration in Sweden, analysing how immigrants' human capital is used and valued in the Swedish labour market, and how this affects labour market outcomes.

Overall, the results indicate that origin-country human capital is devalued in the Swedish labour market. Immigrants can, however, get their previous knowledge and skills recognized, complemented with domestic human capital, and put to productive use after immigration. Nevertheless, achieving labour market outcomes either on par with the pre-immigration level, or with comparable natives, appears difficult for most. 